\author{
Military Technical College \\ Kobry Elkobbah, Cairo, \\ Egypt.
}

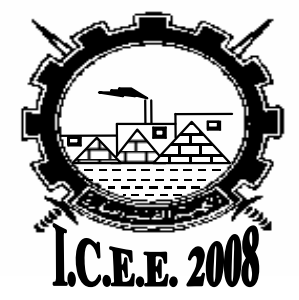

$4^{\text {th }}$ International Conference On

Chemical \& Environmental Engineering

27-29 May 2008

\title{
RECENT TRENDS IN THE CLEANING OF DIESEL FUELS VIA DESULFURIZATION PROCESSES
}

\author{
S. A. HANAFI* and M. S. MOHAMED*
}

\begin{abstract}
This paper is a selective review of new approaches and emerging technologies for ultra-clean (ultra-low sulfur) diesel fuels. The issues of diesel deep desulfurization are becoming more serious because some crude oils are higher in sulfur contents, while the regulated sulfur limits are becoming lower and lower. Deep reduction of diesel sulfur (from 500 to $<15$ ppmw sulfur) is dictated largely by 4,6dimethyldibenzothiophene, which represents the least reactive sulfur compound that have substitutions on both 4- and 6- positions. The deep HDS problem of diesel streams is exacerbated by the inhibiting effects of co-existing polyaromatics and nitrogen compounds in the feed as well as, $\mathrm{H}_{2} \mathrm{~S}$ in the product. New and more effective approaches and continuing catalysis and processing researches are needed for producing affordable ultra-clean diesel fuels, in order to meet the new government sulfur regulations in 2006-2010. Desulfurization research should also take into consideration the fuel-cell fuel processing needs, which will have stringent requirement on desulfurization.
\end{abstract}

\section{KEY WORDS}

Clean diesel fuel, Ultra-deep desulfurization, Refining industry, Catalytic process, Biofuels, Alternative solutions

\footnotetext{
* Egyptian Petroleum Research Institute(EPRI), Nasr City, Cairo

* Egyptian Petroleum Research Institute(EPRI), Nasr City, Cairo
} 


\section{1- INTRODUCTION:}

Clean fuels research including desulfurization has become an important subject of environmental catalysis studies worldwide ${ }^{(1-4)}$. The US Clean Air Act Amendments of 1990 and the new regulations by the US Environmental Protection Agency (EPA), and government regulations in many countries call for the production and use of more environmentally friendly transportation fuels with lower contents of sulfur. Tables 1 and 2 show the current US EPA regulations for gasoline ${ }^{(5)}$ and diesel fuels ${ }^{(6.7)}$ including non-road diesel fuels ${ }^{(8)}$, respectively, along with earlier fuel specification data in the US for comparison ${ }^{(9-10)}$. With the new US EPA Tier II regulations to reduce the gasoline sulfur from current maximum of 350-30 ppmw by 2006, and to cut the highway diesel fuel sulfur from current 500 ppmw down to 15 ppmw by June 2006, refineries are facing major challenges to meet the fuel sulfur specification. EPA has announced plan to reduce non-road diesel fuel sulfur from current average of 3400 ppmw down to 500 ppmw by 2007 and further to 15 ppmw by $2010^{(11,12)}$.

Table (1): US EPA Tier II gasoline sulfur regulation ${ }^{(5)}$.

\begin{tabular}{|l|l|l|c|c|}
\hline \multicolumn{1}{|c|}{ Year } & \multicolumn{1}{|c|}{1988} & \multicolumn{1}{c|}{1995} & $\mathbf{2 0 0 5}$ & $\mathbf{2 0 0 6}$ \\
\hline $\begin{array}{l}\text { Refinery } \\
\text { average } \\
\text { (ppmw) }\end{array}$ & $\begin{array}{l}1000 \\
\text { (maximum) }^{(10)}\end{array}$ & $\begin{array}{l}<330 \text { ppmw S and < 29.2\% } \\
\text { aromatics required for national } \\
\text { certification }\end{array}$ & 30 & 30 \\
\hline
\end{tabular}

Table (2): US EPA sulfur regulations for diesel and fuels ${ }^{(8)}$.

\begin{tabular}{|l|l|l|l|l|}
\hline \multicolumn{1}{|c|}{ Year } & \multicolumn{1}{c|}{1989} & \multicolumn{1}{c|}{1993} & \multicolumn{1}{c|}{2006} & \multicolumn{1}{c|}{2010} \\
\hline $\begin{array}{l}\text { Highway } \\
\text { diesel (ppmw) }\end{array}$ & $\begin{array}{l}\text { 5000 with } \\
\text { minimum } \\
\text { cetane no. } \\
40^{(10)}\end{array}$ & $\begin{array}{l}500 \text { (current } \\
\text { upper limit } \\
\text { since 1993 }\end{array}$ & $\begin{array}{l}15 \text { (regulated in } \\
2001 \text {; exclude } \\
\text { some small } \\
\text { refineries) }\end{array}$ & $\begin{array}{l}15 \text { (regulated } \\
\text { in 2001; apply } \\
\text { to all refineries }\end{array}$ \\
\hline $\begin{array}{l}\text { Non-road } \\
\text { diesel (ppmw) }\end{array}$ & $20000^{(10)}$ & 5000 & $\begin{array}{l}500 \text { (proposed in } \\
2003 \text { for 2007) }\end{array}$ & $\begin{array}{l}15 \text { (proposed } \\
\text { in 2003 for } \\
2010)\end{array}$ \\
\hline
\end{tabular}

The problem of deep removal of sulfur has become more serious due to the lower and lower limit of sulfur content in finished fuel products by regulatory specifications, and and higher sulfur contents in crude oils. A survey of the data on crude oil sulfur content and ÅPI gravity for the past two decades reveals a trend that US refining crude slates continue towards higher sulfur contents and heavier feeds. The average sulfur contents of all the crude oils refined in the five regions of the US known as five Petroleum Administration for Defense Districts (PADDs) increased from $0.89 \mathrm{wt} \%$ in 1981 to $1.42 w t \%$ in 2001, while the corresponding ÅPI gravity decreased from 33.74 
in 1981 to $30.49 \AA ̊ P I$ in $2001^{(13-15)}$. The problem for diesel desulfurization is also somewhat more serious in the US because a higher proportion of light cycle oil (LCO) from FCC is used in the diesel pool in the US ${ }^{(16)}$, which has higher contents of more refractory sulfur compounds (see below). $\mathrm{H}_{2}$ demand increase is another challenge to the refinery operations. Hydrogen deficient are processing restraints and will impact future hydrotreating capabilities and decisions ${ }^{(17)}$.

The heightened interests in ultra-clean fuels, are also due to the need for using new emission control technology of IC engines (especially those for diesel fuels), and for using on-board or on-site reforming of hydrocarbons fuels for new fuel cell vehicles $^{(18)}$.

This article is a selective overview on new design approaches and associated catalysis and chemistry, as well as, processes for deep desulfurization of hydrocarbon fuels, particularly diesel fuels.

\section{2- CHALLENGES OF ULTRA-DEEP DESULFURIZATION OF DIESEL FUELS:}

\section{1- Reactivity of organic sulfur compounds in hydrodesulfurization (HDS):}

Fig. 1 present a qualitative relationship between the type and size of sulfur molecules in various distillate fuel fractions and their relative reactivities ${ }^{(19)}$. Various refinery streams are used to produce three major types of transportation fuels, gasoline, jet fuels and diesel fuels that differ in composition and properties. For the sulfur compounds without a conjugation structure between the lone pairs on $S$ atom and the m-electrons of the aromatic ring, including disulfides, sulfides, thiols and tetrahydrothiophene, HDS occurs directly through hydrogenolysis pathway. These sulfur compounds exhibit higher HDS reactivity than that of thiophene by an order of magnitude, because they have higher electron density on the $S$ atom and weaker C-S bond. The reactivities of the 1- to 3- ring sulfur compounds decrease in the order thiophenes $>$ benzothiophenes $>$ dibenothiophenes ${ }^{(20)}$. In gas oils, the reactivities of (alkyl - substituted) 4-methyldibenzothiophene and 4,6-dimethyldibenzothiophene $(4,6-D M D B T)$ are much lower than those of other sulfur-containing compounds ${ }^{(20,21)}$. Recently, investigations have demonstrated that sulfur compounds remaining in diesel fuels at sulfur level lower than $500 \mathrm{ppm}$ by conventional HDS are the dibenzothiophenes with alkyl substituents at the 4- and/or 6- position ${ }^{(18)}$. These species are termed refractory sulfur compounds ${ }^{(22)}$. Both steric hindrance and electronic factor are responsible for the observed low reactivity of these refractory sulfur compounds ${ }^{(18)}$. The shape of these molecules "hides" the sulfur from the catalyst, making it difficult to remove by the conventional desulfurization mechanism ${ }^{(23,24)}$. To remove these molecules, the molecular structure must be changed by saturating one of the aromatic rings. This twists the molecule, making the sulfur more accessible ${ }^{(25)}$. Consequently, in deep HDS, the conversion of the refractory sulfur compounds largely determines the required conditions ${ }^{(26)}$.

Therefore, petroleum refining industry is facing a major challenge to meet the new stricter sulfur specifications in the early $21^{\text {st }}$ century where the quality of the crude oils decline in terms of increased sulfur content and decreased ÅPI gravity ${ }^{(27)}$. 


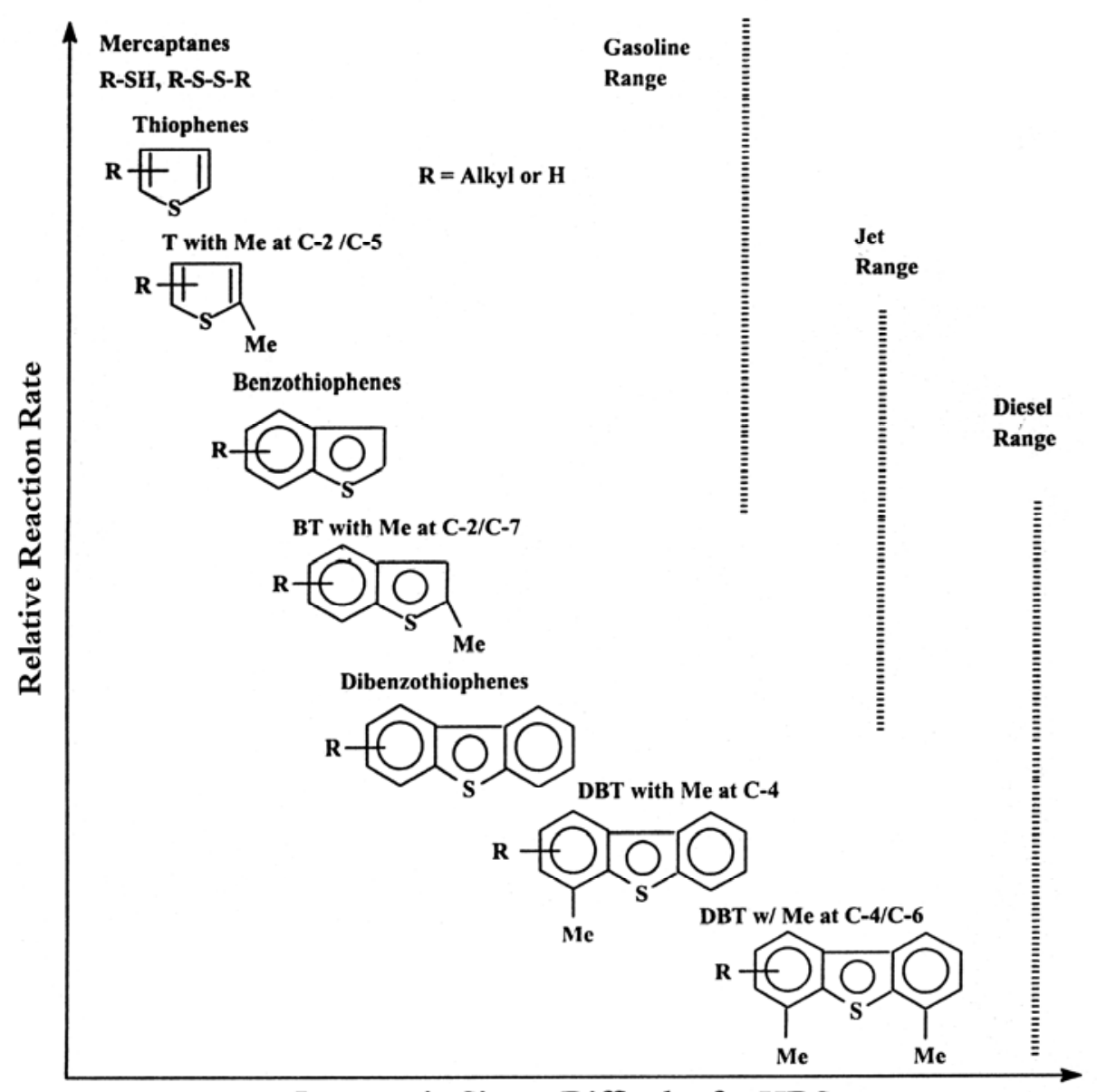

Increase in Size \& Difficulty for HDS

Fig. 1: Reactivity of various organic Sulfur compounds in HDS versus their ring sizes and positions of alkyl substitutions on the ring.

\section{2- Mechanistic pathways:}

Substantial progress has been made in fundamental understanding and practical applications of hydrotreating catalysis and metal sulfide-based catalysts for HDS as discussed in several excellent reviews ${ }^{(22,25,28,29)}$. The following discussion focuses on deep desulfurization of polycyclic sulfur compounds.

HDS of thiophenie compounds proceeds through two pathways (scheme 1): hydrogenation pathway (hydrogenation followed by hydrogenolysis) and the direct hydrogenolysis pathway (direct elimination of $\mathrm{S}$ atom via C-S bond cleavage) ${ }^{(30-33)}$. Hydrogenation and hydrogenolysis occur at different active sites. Data for DBTs could be arranged by the Langmuir-Hinshelwood rate equation. Activation energies of DBT, 4-MDBT and 4,6-DMDBT were 24, 31 and $40 \mathrm{k} \mathrm{cal} / \mathrm{mol}$, respectively. Heats of adsorption for DBT, 4-MDBT and 4,6-DMDBT were 12, 20 and $21 \mathrm{k} \mathrm{cal} / \mathrm{mol}$, respectively $^{(34)}$. Kab et al ${ }^{(34)}$ proposed that 4-MDBT or 4,6-DMDBT can be adsorbed on the catalyst through $\pi$-electron in the aromatic rings more strongly than that of DBT and that the C-S bond cleavage of adsorbed DBTs is disturbed by steric hindrance of the methyl group ${ }^{(34)}$. Previous studies have demonstrated that over the industrial HDS catalysts, the refractory sulfur compounds, particularly 4,6-DMDBT 
are desulfurized dominantly by the hydrogenation pathway as the alkyls at the 4and/or 6- position of DBT strongly block the hydrogenoloysis pathway ${ }^{(32,35)}$.

Hydrogenation of 4,6-DMDBT leads to a flexible cyclohexyl ring. The hydrogenated ring can adopt several conformations, in some of which the bulky methyl substituent is rotated away from the sulfur atom. This decreases the steric hindrance of the methyl groups located at positions 4 and 6 and makes the sulfur atom more accessible for desulfurization. Furthermore, the lengths of the $\mathrm{C}-\mathrm{S}$ bonds increase with the degree of saturation of the molcuels, making these bonds more reactive ${ }^{(36)}$.

As desulfurization of the refractory sulfur compounds occurs dominantly through the hydrogenation pathway, the inhibition of the coexistent aromatics towards HDS of the refractory sulfur compounds by competitive adsorption on the hydrogenation active sites becomes stronger in deep $\operatorname{HDS}^{(37)}$.

$\mathrm{H}_{2} \mathrm{~S}$ produced from reactive sulfur compounds in the early stage of the reaction is one of the main inhibitors for HDS of the unreactive species ${ }^{(38,39)}$.

Other feed impurities such as $\mathrm{N}$-compounds, are inhibitors for the hydrogenative HDS route. These strong $\pi$-bonding species hinder the interaction of the refractory $S$ compounds with the active catalytic site ${ }^{(40-42)}$.

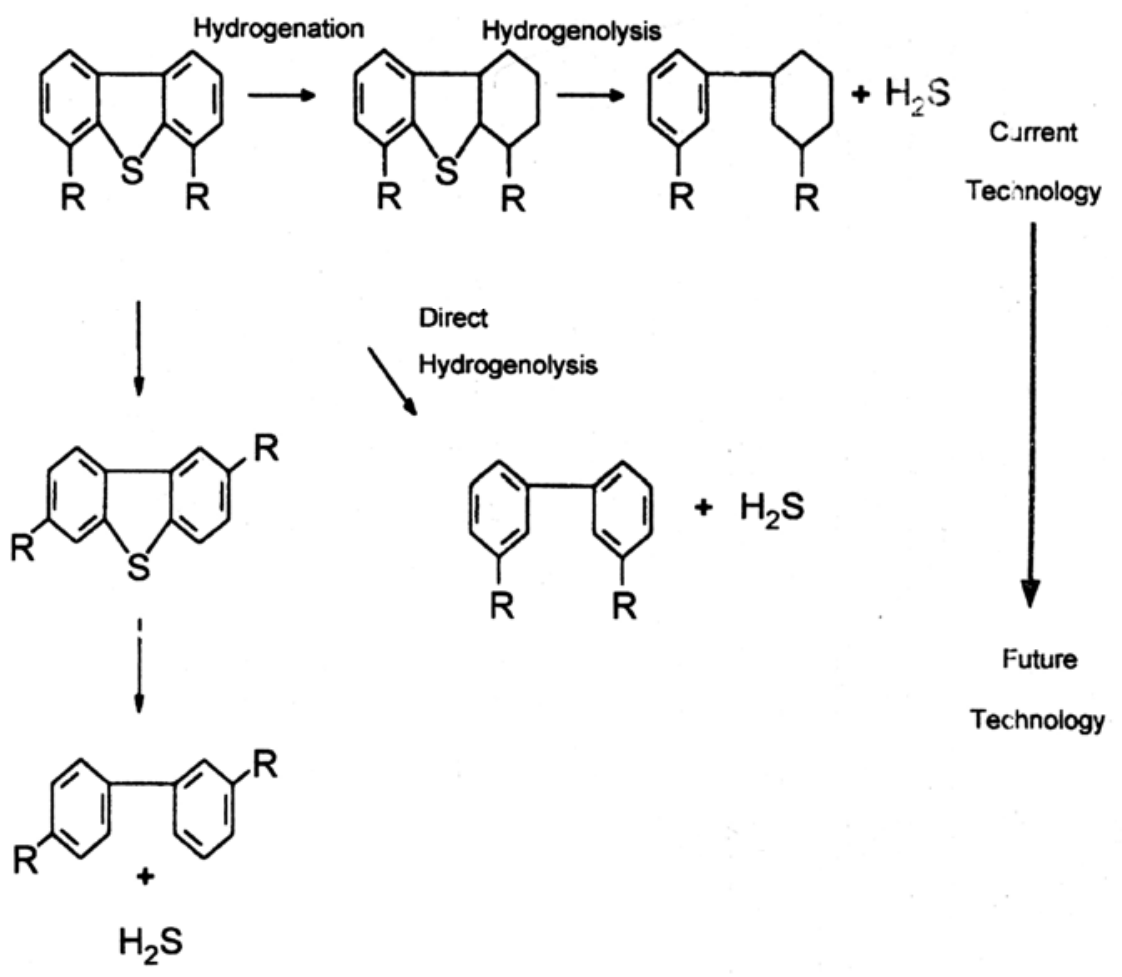

Scheme 1: HDS reaction pathways

\section{3- Catalyst formulations for HDS:}

The basic compositions of current HDS catalysts are represented by molybdenum sulfide promoted by cobalt or nickel and supported on porous $\gamma$-alumina, Co$\mathrm{Mo} / \mathrm{Al}_{2} \mathrm{O}_{3}, \mathrm{Ni}-\mathrm{Mo} / \mathrm{Al}_{2} \mathrm{O}_{3}$, with various modifications by using additives (e.g., boron or phosphorus), more promoters (e.g., $\mathrm{Ni}-\mathrm{CoMo} / \mathrm{Al}_{2} \mathrm{O}_{3}$ ) or improved preparation methods. The activity and selectivity of the hydrotreating catalysts have been 
improved significantly as a result of continuous research and development in research institutions and catalysts, and petroleum companies worldwide ${ }^{(43-48)}$.

An excellent review has been published by Topsoe et al. ${ }^{(49)}$ on chemistry and catalysis by metal sulfides. Design approaches for developing more active catalysts are based on the ideas to tailor the active sites for desired reactions. The exact nature of active sites in Co-Mo or Ni-Mo catalysts is still a subject of debate, but the Co-Mo-S model (or Ni-Mo-S model for Ni-Mo catalysts) is currently the one most widely accepted ${ }^{(49,50)}$. According to the model, the Co-Mo-S structure or Ni-Mo-S structure is responsible for the catalytic activity of the Co-promoted or Ni-promoted $\mathrm{MoS}_{2}$ catalyst, although the model does not specify whether the catalytic activity arises from Mo promoted by Co or from cobalt promoted by molybdenum. Densityfunctional theory calculations show that addition of $\mathrm{Co}^{-\mathrm{MoS}_{2}}$ structure lowers the sulfur binding energy at the edges and thereby provides more active sites ${ }^{(51)}$. The formation of sulfur vacancy in $\mathrm{MoS}_{2}$ under $\mathrm{H}_{2}$ atmosphere has been observed directly for the first time by scanning tunneling microscope $(\mathrm{STM})^{(52)}$.

Among the Co-Mo-S structure, for alumina-supported catalysts, the intrinsically more active phase was referred to as type II (Co-Mo-S II), and the less active phase as type I (Co-Mo-S I). Type I structure is assumed to be bonded to support through MoO-Al linkages and has less stacking, whereas type II structure has higher stacking and few linkages with support ${ }^{(50)}$. For steric reasons, catalyst-support linkages in CoMo-S I probably hinder reactant molecules from approaching the catalytically active sites, and thus Co-Mo-S II is more active than Co-Mo-S I. Daage and Chianelli( ${ }^{(53)}$ reported that the top and bottom layers (rim) of unsupported $\mathrm{MoS}_{2}$ stacks (slabs) have a much higher activity than the surface of intermediate layers (edge) for hydrogenation of BDT, while the hydrogenolysis of the C-S bond in DBT occurs equally well on all $\mathrm{MoS}_{2}$ layers. They proposed a rim-edge model, and explained that the $\pi$-adsorption on $\mathrm{MoS}_{2}$ surface results in hydrogenation of DBT which can take place on rim sites but this adsorption is more difficult on edge sites, whereas vertical adsorption of sulfur is assumed to be necessary for C-S bond hydrogenolysis which can take place on surface Mo sites of all layers (both rim and edge). The Co-Mo-SI model makes no distinction between rim and edge, but Co-Mo-SII would seem to have relatively more rime sites that are not likely to be influenced by steric hindrance of reactant adsorption. Consequently, more Co-Mo-SII structures can lead to more active catalysts for desulfurization of polycyclic sulfur compounds.

\section{4- Design approaches to ultra deep desulfurization of diesel:}

Approaches to ultra-deep desulfurization include: (1) improving catalytic activity by new catalyst formulation for HDS of 4,6-DMDBT; (2) tailoring reaction and process conditions; (3) designing new reactor configurations; and (4) developing new processes. Design approaches for ultra-deep HDS focus on how to remove 4,6DMDBT more effectively. One or more approaches may be employed by a refinery to meet the challenges of producing ultra-clean fuels at affordable cost. Table 3 outlines processing approaches for ultra-deep desulfurization to produce ultra-low-sulfur diesel ${ }^{(19,54)}$, where the processes for reducing sulfur content in diesel feedstock can be grouped according to the treatment around FCC; including: (1) post-treating product to remove sulfur from FCC LCO as well as other gas oil streams; (2) pretreating the FCC feed to remove sulfur, and (3) increasing sulfur conversion in situ to hydrogen sulfide during the FCC operation. General processing methods and 
developers are listed below for desulfurization of gas oil streams (including LCO from FCC, CGO from delayed coker, and straight - run gas oil, etc.). Some selected approaches are elaborated below.

Table (3): Approaches to deep desulfurization for cleaner diesel fuels.

\begin{tabular}{|c|c|c|}
\hline Category & Description and representative process & Remarks \\
\hline \multirow[t]{12}{*}{$\begin{array}{l}\text { (I) Post-FCC and non-FCC } \\
\text { distillate } \mathrm{S} \text { removal }\end{array}$} & $\begin{array}{l}\text { Apply conventional HDS of middle distillates with higher } \\
\text { process severity (many companies can apply hydrotreating } \\
\text { with longer residence time or at higher temperature) }\end{array}$ & HDS at higher severity \\
\hline & $\begin{array}{l}\text { Uitra-deep HDS of middle distillate (MAKFining premium } \\
\text { distillates technology (PDT) by Akzo Noble, ExxonMobil, } \\
\text { and Kellog Brown) }\end{array}$ & HDS with more active catalysts \\
\hline & $\begin{array}{l}\text { Ultra-deep HDS (SynHDS) and hydrodearomatization } \\
\text { (SynSat) and cetane improvement by ring-opening (SynShif) } \\
\text { of middle distillate (SynTechnology including new reactor } \\
\text { design by SynAlliance including ABB Lummus, Criterion } \\
\text { Catalyst, and Shell Global) }\end{array}$ & $\begin{array}{l}\text { HDS with new reactor } \\
\text { design and better catalysts }\end{array}$ \\
\hline & $\begin{array}{l}\text { Two-stage hydrotreating for ultra-low-sulfur diesel fuel using } \\
\text { industrially proven high-activity TK catalysts (Haldor-Topsoe) }\end{array}$ & HDS in staged operation \\
\hline & $\begin{array}{l}\text { Ultra-deep HDS, hydrodenitrogenation and hydrogenation of } \\
\text { distillate fuels (Unionfining by UOP; Prime-D by IFP) }\end{array}$ & HDS, HDN and HDAr \\
\hline & $\begin{array}{l}\text { Hydrodearomatization (HDAr) of middle distillate in the } \\
\text { sccond stage (MAKFining Premium Distillates Technology } \\
\text { (PDT) by Akzo Noble, ExxonMobil, and Kellog Brown) }\end{array}$ & HDAr after HDS \\
\hline & $\begin{array}{l}\text { Sulfur adsorption and capture by solid metal-based adsorbent } \\
\text { at elevated temperatures under low } \mathrm{H}_{2} \text { pressure (Phillips } \\
\text { Petroleum S-Zorb Diesel) }\end{array}$ & $\begin{array}{l}\text { Non-HDS, stoichiometric } \mathrm{H}_{2} \\
\text { consumption }\end{array}$ \\
\hline & $\begin{array}{l}\text { Sulfur adsorption and capture by solid metal oxide sorbent at } \\
\text { high temperatures (RTI TReND) }\end{array}$ & Non-HDS, with $\mathrm{H}_{2}$ atmosphere \\
\hline & $\begin{array}{l}\text { Selective adsorption for removing sulfur (SARS) as organic } \\
\text { compounds by solid adsorbent at ambient temperature } \\
\text { without using } \mathrm{H}_{2} \text { (Pennsylvania State University, PSU-SARS) }\end{array}$ & $\begin{array}{l}\text { Adsorption, no } \mathrm{H}_{2} \text {; can reach } \\
<1 \mathrm{ppm} \mathrm{S} \text { for fuel cells }\end{array}$ \\
\hline & $\begin{array}{l}\text { Integrated adsorption and hydrotreating of concentrated sulfur } \\
\text { from adsorption (Pennsylvania State University, } \\
\text { PSU-SARS-HDSCS) }\end{array}$ & Adsorption plus HDS \\
\hline & $\begin{array}{l}\text { Oxidative desulfurization (SulphCo DeS; Unipure ASR-2; } \\
\text { PetroStar DeS) }\end{array}$ & Use peroxide as oxidant \\
\hline & Biochemical desulfurization (Energy BioSystems DeS) & Use bacteria for sulfur oxidation \\
\hline \multirow[t]{2}{*}{ (II) Pre-FCC sulfur removal } & $\begin{array}{l}\text { Deep HDS of feed before catalytic cracking in FCC reactor, } \\
\text { which greatly reduces sulfur in FCC naphtha and in LCO } \\
\text { (Akzo Nobel, IFP, UOP, etc.) }\end{array}$ & $\begin{array}{l}\mathrm{HDS} \text { at higher } \mathrm{H}_{2} \text { pressure } \\
\text { and longer residence time }\end{array}$ \\
\hline & $\begin{array}{l}\text { Physico-chemical treatment such as adsorption or extraction } \\
\text { to remove sulfur (concept suggested here as a possible } \\
\text { approach based on PSU-SARS) }\end{array}$ & Adsorption without $\mathrm{H}_{2}$ \\
\hline \multirow[t]{2}{*}{ (III) In situ FCC sulfur removal } & $\begin{array}{l}\text { Convert more organic sulfur into } \mathrm{H}_{2} \mathrm{~S} \text { during } \mathrm{FCC} \text { operation, } \\
\text { which can reduce organic sulfur in liquid products (Akzo } \\
\text { Nobel's Resolve; Grace Davison's Saturn (GSR-6.1)) }\end{array}$ & Sulfur conversion to $\mathrm{H}_{2} \mathrm{~S}$ in $\mathrm{FCC}$ \\
\hline & $\begin{array}{l}\text { Capture organic sulfur using metal species to retain sulfur as } \\
\text { sulfur oxide, and regenerate it in the regenerator (concept } \\
\text { suggested here as a possible approach based on reactive } \\
\text { adsorption using sorbent) }\end{array}$ & Sulfur capture in FCC \\
\hline
\end{tabular}

\section{1- Improving catalytic activity by new catalyst formulation:}

Design approaches for improving catalytic activity for ultra-deep HDS focus on how to remove 4,6-DMDBT more effectively, by modifying catalyst formulations to: (1) enhance hydrogenation of aromatic ring in 4,6-DMDBT by increasing hydrogenating ability of the catalyst; (2) incorporate acidic feature in catalyst to induce isomerizations of methyl groups away from the 4- and 6-positions; and (3) remove inhibiting substances (such as nitrogen species in the feed, $\mathrm{H}_{2} \mathrm{~S}$ in gas) and tailoring the reaction conditions for specific catalytic functions. The catalytic materials formulations may be improved for better activity and/or selectivity by using different supports (MCM-41, carbon, $\mathrm{HY}, \mathrm{TiO}_{2}, \mathrm{TiO}_{2}-\mathrm{Al}_{2} \mathrm{O}_{3}$, etc). for preparing supported $\mathrm{Co} / \mathrm{Mo}, \mathrm{Ni} / \mathrm{Mo}$ and Ni/W catalysts; by increasing loading level of active metal (Mo, W, etc.); by modifying preparation procedure (using different precursor, using additives, 
or different steps or sequence of metal loading); by using additives or additional promoters ( $\mathrm{P}, \mathrm{B}, \mathrm{F}$, etc.); by adding one more base metal (e.g., Ni-CoMo or Co-NiMo, $\mathrm{Nb}$, etc.); and by incorporating a noble metal ( $\mathrm{Pt}, \mathrm{Pd}, \mathrm{Ru}$, etc.).

New and improved catalysts and different processing schemes are among the subject, of active research on deep $\mathrm{HDS}^{(55-60)}$. For example, some studies examined carbon-supported CoMo catalysts for deep $\mathrm{HDS}^{(61-63)}$. Binary oxide supports have been examined for making improved HDS catalysts ${ }^{(64-66)}$. Mesoporous molecular sieve of MCM-41 type has also been examined as support for Co-Mo/MCM-41 catalyst for deep HDS of diesel fuels ${ }^{(67-69)}$.

\section{2- Commercial HDS catalyst development:}

The catalyst development has been one of the focuses of industrial research and development for deep HDS. For example, new and improved catalysts have been developed and marketed by Akzo Noble, Criterion, Haldor-Topsoe, United catalyst/Sud-Chemie, and Exxon Mobil. Akzo Noble currently markets four CoMo desulfurization catalysts; KF 752, KF 756 and KF 757, which have been available for several years, and KF 848, which was announced in $2000^{(70,71)}$. KF 752 can be considered to be typical of an Akzo Nobel catalyst of the 1992-1993 timeframe, while KF 756 and 757 catalysts represent improvements. Akzo Nobel estimates that under typical conditions (e.g., 500 ppmw sulfur), KF 756 is $25 \%$ more active than KF 752 , while KF 757 is $50 \%$ more active than KF 752 and $30 \%$ more active than KF $756^{(71)}$. However, under more severe conditions (e.g., $<50$ ppmw sulfur), KF 757 is $35-75 \%$ more active than KF 756 . KF 848 is $15-50 \%$ more active than KF 757 . Commercial experience exists for both advanced catalysts. KF 756 was widely used in Europe ( $20 \%$ of all distillate hydrotreaters, operating on $1^{\text {st }}$ January 1998), while KF 757 has been used in at least three hydrotreaters commercially ${ }^{(6)}$.

NEBULA catalyst has bend developed jointly by Exxon Mobil, Akzo Nobel, and Nippon Ketjen and commercialized in $2001^{(72,73)}$.

Haldor-Topsoe has also developed a more active catalyst. Its Tk-554 catalyst is analogous to Akzo Nobel's KF 756 catalyst, while its newer, more active catalyst is termed TK-574.

Criterion Catalyst Company announced two new lines of catalyst. One is called century, and the other is called centinel ${ }^{(55)}$. These two lines of catalysts are reported to be $45-70$ and $80 \%$ more active, respectively, at desulfurizing petroleum fuel than conventional catalysts used in the mid-1990s ${ }^{(6)}$. These improvements have come about through better dispersion of the active metal on the catalyst substrate.

\section{3- Tailoring reaction and processing conditions:}

Tailoring process conditions aims at achieving deeper HDS with a given catalyst in an existing reactor without changing the processing scheme, with no or minimum capital investment. The parameters include those that can be tuned without any new capital investment (space velocity, temperature, pressure), and those that may involve some relatively minor changes in processing scheme or some capital investment (expansion in catalyst volume or density, $\mathrm{H}_{2} \mathrm{~S}$ scrubber from recycle gas, improved vapor-liquid distributor ${ }^{(74-77)}$. First, space velocity can be decreased through increasing the catalyst bed volume or reducing the flow rate of liquid feedstock to increase the reactant-catalyst contact time. More refractory sulfur compounds would require lower space velocity for achieving deeper HDS. Second, temperature can be 
increased, which increases the rate of HDS. Higher temperature facilitates more of the high activation-energy reaction. Third, $\mathrm{H}_{2}$ pressure can be increased. Fourth, improvements can be made in vapor-liquid contact to achieve uniform reactant distribution, which effectively increases the use of surface area of the catalyst. Finally, the concentration of hydrogen sulfide in the recycle stream can be removed by amine scrubbing. Since $\mathrm{H}_{2} \mathrm{~S}$ is an inhibitor to HDS, its build-up in high-pressure reactions through continuous recycling can become significant.

Some of these factors are elaborated further below.

Liquid-hourly space velocity (LHSV) and catalytic bed volume are inter-related parameters that control both the level of sulfur reduction and the process throughput. Increase in catalyst bed volume can enhance HDS. UOP projects that doubling reactor volume would reduce sulfur from 120 to $30 \mathrm{ppmw}^{(6)}$.

Increasing the temperature of reaction can enhance the desulfurization of more refractory sulfur compounds. Haldor-Topsoe showed that an increase of $14^{\circ} \mathrm{C}$ while processing a mixture of SRLGO and LCO with its advanced TK-574 Co-Mo catalyst will reduce sulfur from 120 to $40 \mathrm{ppmw}^{(6)}$. The downside of increased temperature is the reduction of catalyst life ${ }^{(76)}$. This increases the cost of catalyst, as well as, affects highway diesel fuel production while the unit is down for the catalyst change.

Role of $\mathrm{H}_{2} \mathrm{~S}$ in deep HDS of gas oils has been discussed in detail by $\mathrm{Sie}^{(78)}$. The decrease in the concentration of $\mathrm{H}_{2} \mathrm{~S}$ in gas phase could reduce the inhibition of the desulfurization ${ }^{(79,80)}$ and hydrogenation reactions. $\mathrm{H}_{2} \mathrm{~S}$ can be removed by chemical scrubbing. UOP projects that scrubbing $\mathrm{H}_{2} \mathrm{~S}$ from recycle hydrogen can reduce sulfur levels from roughly 285 to 180 ppmw in an existing hydrotreater ${ }^{(6)}$.

The increase in $\mathrm{H}_{2}$ partial pressure and/or purity can improve HDS and hydrogentation. Holder-Topsoe showed that an increase in hydrogen purity of $30 \%$ would lower the temperature needed to achieve the same sulfur removal rate by 8$9^{\circ} \mathrm{C}$. Or temperature could be maintained while increasing the amount of sulfur removed by roughly $40 \%{ }^{(6)}$.

Increasing, the recycle gas/oil ratio (increase in the amount of recycle gas sent to the inlet of the reactor) could increase the degree of desulfurization, but the effect is relatively small so a relatively large increase is needed to achieve the same effect as scribing recycle gas ${ }^{(12)}$. Haldor-Topsoe indicated that a $50 \%$ increase in the ratio of total gas/liquid ratio only decreases the necessary reactor temperature by $6-8^{\circ} \mathrm{C}$; or temperature can be maintained and the final sulfur level reduced by $35-45 \%{ }^{(6)}$.

The improvement in vapor-liquid contact can enhance the performance of distillate hydrotreaters. Akzo Nobel estimated that an improved vapor-liquid distributor can reduce the temperature necessary to meet a 50 ppmw sulfur level by $10^{\circ} \mathrm{C}$, which in turn would increase catalyst life and allow an increase in cycle length from 10 to 18 months ${ }^{(6)}$.

The above-mentioned individual improvements described cannot be simply combined. As each existing distillate hydrotreater is unique in its combination of design, catalyst, feedstock, and operating conditions. While the improvements described above are probably indicative of improvements which can be made in many cases, it is not likely that all of the improvements mentioned are applicable to any one unit; the degree of improvement at one refinery could either be greater than, or less than the benefits that are indicated for another refinery. 


\section{4- Designing new reactor configurations:}

Industrial reactor configuration for deep HDS of gas oils in terms of reaction order and effect of $\mathrm{H}_{2} \mathrm{~S}$ has been discussed ${ }^{78,81-87)}$. The reactor design and configuration involve one-stage and two-stage desulfurization as shown in Fig. $2^{(23,87)}$. Hydrogen sulfide strongly suppresses the activity of the catalyst for converting the refractory sulfur compounds which should occur in the major downstream part of a co-current trickele-bed reactor during deep HDS. The normally applied Co-current trickle-bed single reactor is therefore not the optimal technology for deep HDS ${ }^{(78)}$. However, a second reactor can be used, particularly to meet lower sulfur levels. Adding a second reactor to increase the degree of desufurization is an option, and both desulfurization and hydrogenation in the second reactor can be improved by removing $\mathrm{H}_{2} \mathrm{~S}$ and $\mathrm{NH}_{3}$ from the exit gas of first reactor before entering the second reactor. This last technical change is to install a complete second stage to the existing one-stage hydrotreater. This second stage would consist of a second reactor, and a high pressure, hydrogen sulfide scrubber between the first and second reactor ${ }^{(86)}$. The compressor would also be upgraded to allow a higher pressure to be used in the new second reactor ${ }^{(85)}$. Assuming use of the most active catalysts available in both reactors, UOP projects that converting from one-stage to a two-stage hydrotreater could produce 5 ppmw sulfur relative to a current level of 500 ppmw today ${ }^{(6)}$.

A new way of reactor design is to have two or three catalyst beds, that are normally placed in separate reactors, within a single reactor shell and have both co-current and counter-current flows ${ }^{(78)}$. This new design was developed by ABB Lummus and Criterion called Syn Technology ${ }^{(88,89)}$. With this technology, in a single reactor design, the initial portion of the reactor will follow a co-current design, while the last portion of the reactor will be counter-current ${ }^{(6)}$. Traditional reactors are co-current in nature. The hydrogen is mixed together with the distillate at the entrance to the reactor and flow through the reactor together. Because the reaction is exothermic, heat must be removed periodically. This is sometimes done through the introduction of fresh hydrogen and distillate at one or two points further down the reactor. The advantage of co-current design is practical, it eases the control of gas-liquid mixing and contact with the catalyst. The disadvantage is that the concentration of $\mathrm{H}_{2}$ is the highest at the front of the reactor and lowest at the outlet. The opposite is true for the concentration of $\mathrm{H}_{2} \mathrm{~S}$. This increases the difficulty of achieving extremely low-sulfur levels due to the low $\mathrm{H}_{2}$ concentration and high $\mathrm{H}_{2} \mathrm{~S}$ concentration at the end of the reactor. A new solution to this problem is to design a counter-current reactor, where the fresh $\mathrm{H}_{2}$ is introduced at one end of the reactor and the liquid distillate at the other end (Fig. 3). Here, the hydrogen concentration is highest (and the $\mathrm{H}_{2} \mathrm{~S}$ concentration is lowest) where the reactor is trying to desulfurize the most difficult compounds. The difficulty of counter-current design in the case of distillate hydrotreating in vapor-liquid contact and the prevention of hot spots within the reactor.

In a two-reactor design, the first reactor will be co-current, while the second reactor will be counter current. ABB Lummus estimated that the counter current design can reduce the catalyst volume needed to achieve $97 \%$ HDS by $16 \%$ relative to a-cocurrent design ${ }^{(6)}$. The impact of the counter-current design is even more significant when aromatics control (or cetane improvement) is desired in addition to sulfur control. However, operation of counter-current flow reactor might not be possible in packed beds of the usual catalyst particles because of the occurrence of flooding at 
industrially relevant fluid velocities. Criterion offers the catalysts for the Syn-Sat and Syn Shift processes. Syn Shift involves deep heteroatom removal, ring opening, and aromatic, saturation thus decreasing (shifting) boiling range ${ }^{(78)}$.

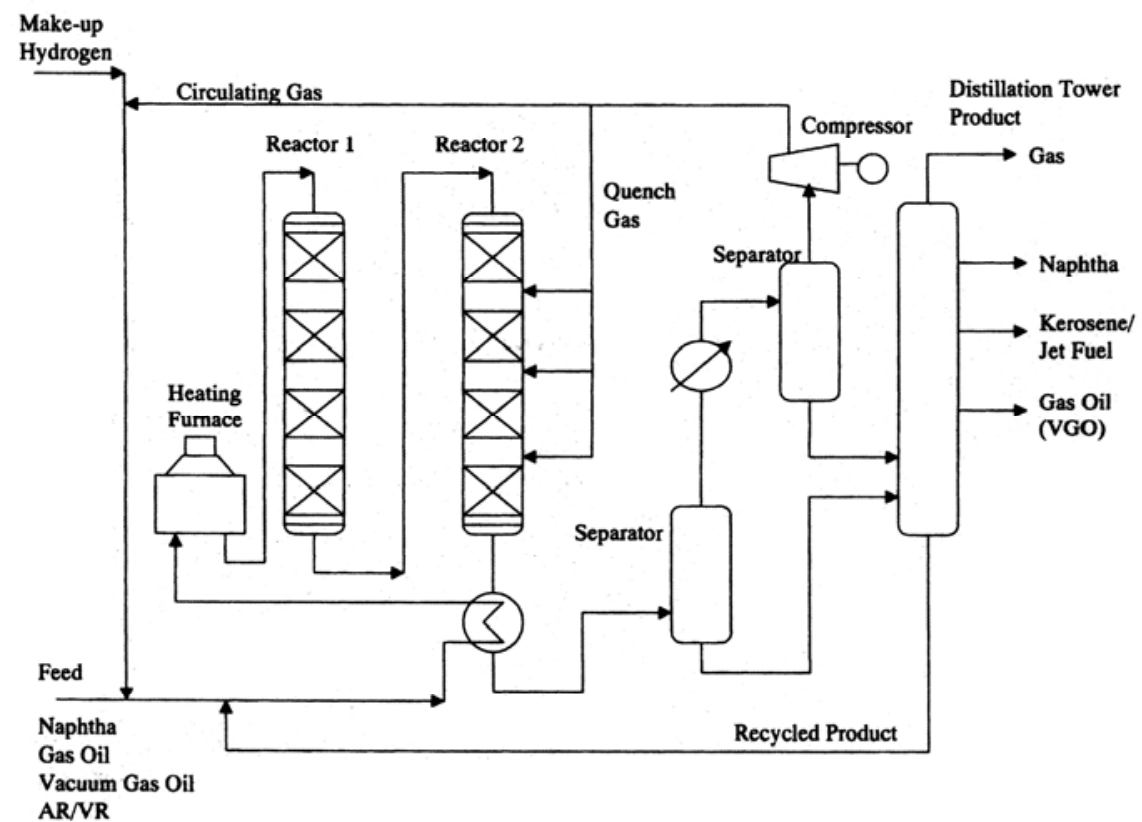

Fig. 2: Single-Stage Process Flow Diagram

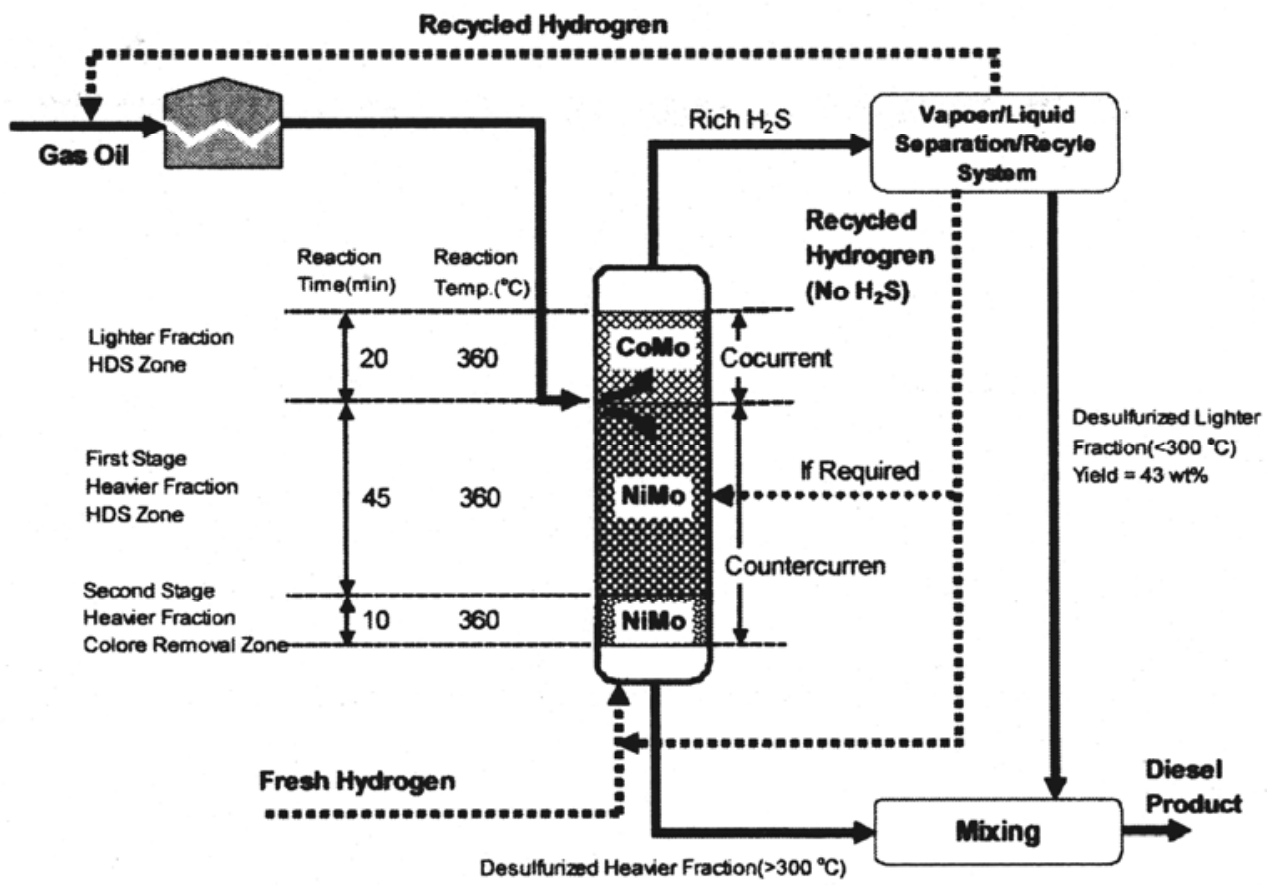

Fig. 3: Reactor Design for Deep HDS

\section{5- Developing new processes:}

Among the new process concepts, design approaches for ultra-deep desulfurization focus on: (1) adsorption and sulfur atom extraction by using reduced metals to react with sulfur to form metal sulfides at elevated temperatures under $\mathrm{H}_{2}$ atmosphere without hydrogenation of aromatics; (2) selective adsorption of sulfur compounds- 
remove sulfur by selective interaction with sulfur compounds in the presence of aromatic hydrocarbons under ambient or mild conditions without hydrogen; (3) oxidation and extraction-oxidize sulfur compounds by liquid-phase oxidation reactions with or without ultrasonic radiations, followed by separation of the oxidized sulfur compounds; and (4) biodesulfurization by using bacteria via microbial desulfurization.

\subsection{1- Reactive adsorption for sulfur capture and S-Zorb process:}

Phillips Petroleum conducted an internal study of its refineries and concluded the use of hydrotreating technologies to reach ultra-low sulfur levels to be a cost-prohibitive option $^{(90-94)}$. A prospective diesel desulfurization process, S-Zord diesel, was announced by Phillips Petroleum, which is an extension of their S-Zorb process for gasoline (at $\left.377-502^{\circ} \mathrm{C}, 7.0-21.1 \mathrm{~kg} / \mathrm{cm}^{2}\right)^{(90)}$. S-Zorb for diesel contacts highway diesel fuel (typically) with about 350 ppmw sulfur) with a solid sorbent in a fluid bed reactor at relatively low pressures and temperatures in the presence of hydrogen (Fig. 4). The sulfur atom of the sulfur-containing compounds adsorbs onto the sorbent and reacts with the sorbent. Phillips Petroleum used a proprietary sobent that attracts sulfur-containing molecules and removes the sulfur atom from the molecule. The sulfur atom is retained on the sorbent while the hydrocarbon portion of the molecules is released back into the process stream. Hydrogen sulfide is not released into the product stream and therefore prevents recombination reactions of hydrogen sulfide and olefins to make mercaptans, which would otherwise increase the effluent sulfur concentration. Based on the principle, it appears that the sorbent is based on reduced metal that reacts with sulfur to become metal sulfide. The spent sorbent is continuously withdrawn from the reactor and transferred to the regenerator section. In a separate regeneration vessel, the sulfur is burned off of the sorbent and $\mathrm{SO}_{2}$ is drawn to the sulfur plant. The cleaned sorbent is further reduced by hydrogen and the regenerated sorbent is then recycled back to the reactor for removing more sulfur. The rate of sorbent circulation is controlled to maintain the desired sulfur concentration in the product. Because the sorbent is continuously regenerated, Pillips proposed that the unit will be able to operate 4-5 years between shutdown ${ }^{(72)}$. Because untreated distillate can contain several \% sulfur, Phillips believes that the SZorb process for diesel could get over whelmed by the amount of sulfur which is adsorbed onto the sorbent. Thus, the S-Zorb process may not be able to treat untreated distillate streams but would likely be used to treat distillate containing 500 ppmw sulfur or less ${ }^{(72,91)}$. 


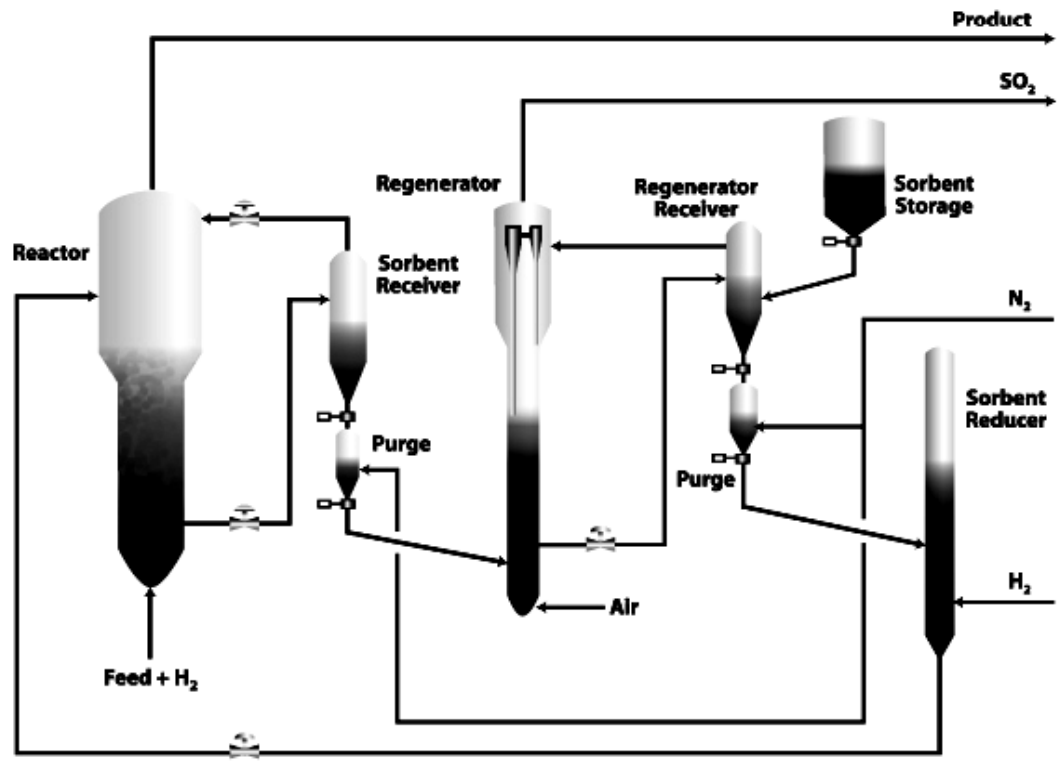

Fig. 4: S Zorb Unit

\subsection{2- Selective adsorption for deep desulfurization at ambient temperature (SARS):}

An alternate process for deep desulfurization of distillate fuels (diesel, gasoline and jet fuels) based on selective adsorption for removal of sulfur compounds (SARS) at ambient conditions without using $\mathrm{H}_{2}{ }^{(95-99)}$. Fig. 5 illustrates the known coordination geometries of thiophene in organometallic complexes, which indicate likely adsorption configurations of thiophenic compounds on the surface of adsorbents. Both thiophenic compounds and non-suflur aromatic compounds can interact with metal by m-electrons. However, in Fig. 5 only two types of interaction of thiophene with metal involve sulfur atom in thiophene, the $\eta$ 's bonding interaction between the sulfur atom and one metal atom, and the $\mathrm{S} \mu 3$ bonding interaction between the sulfur atom and two metal atoms ${ }^{(100,101)}$.
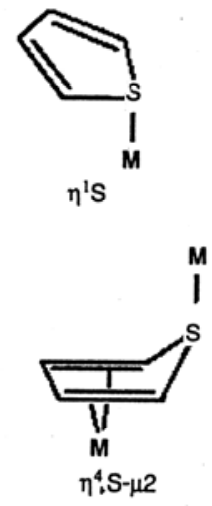
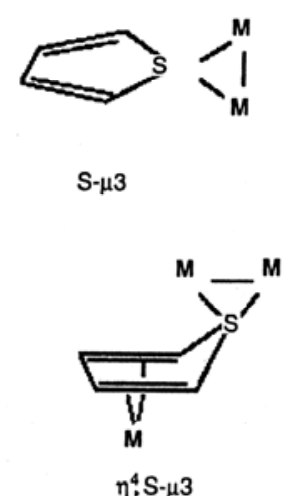

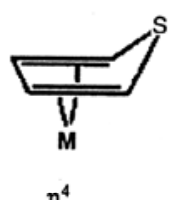

$\eta^{4}$

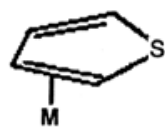

$\eta^{2}$

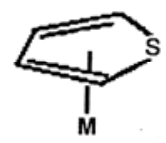

$\eta^{5}$

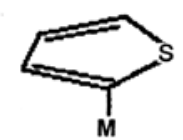

$\eta^{\prime} \mathrm{C}$

Fig. 5: Known coordination geometries of thiophene in organometallic complexes, indicating likely adsorption configurations of thiophenic compounds on the surface of adsorbents

\subsection{3- New integrated process based on adsorption:}


By using conventional HDS processes, the refiners need to process $100 \%$ of the fuel for dealing with sulfur compounds that account for less than $0.3 \mathrm{wt} \%$. of the feed with 500 ppmw sulfur level. Fig. 6 shows the flow diagram of the proposed concept of the new integrated desulfurization process, which consists of selective adsorption for removal of sulfur compounds (SARS) followed by HDS of concentrated sulfur compounds using high-activity catalysts such as Co-Mo/MCM- $41^{(102)}$. The subsequent HDS of sulfur compounds removed by selective adsorption is much easier than conventional HDS of diesel streams for two reasons. First, it is more concentrated and thus reactor utilization is more efficient. Second, the rate of HDS reaction is faster because of the removal of aromatics which inhibit the HDS by competitive adsorption in the hydrogenation sites. Third, and most important for practical application, the reactor volume can be made substantially smaller because the amount of fuel to be processed is smaller by $95 \%$ or more.

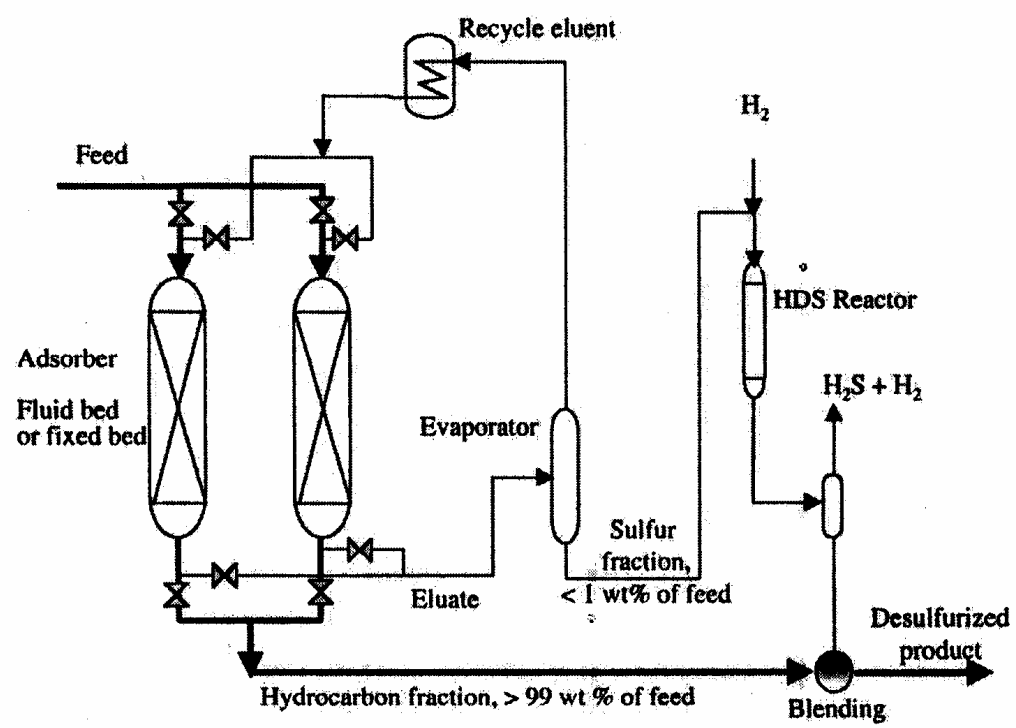

Fig. 6: The Proposed Adsorption Process for Deep Desulfurization

\subsection{4- Adsorption of polar nitrogen compounds before diesel HDS:}

Adsorption of polar substances can be used as a pretreatment to remove nitrogen before HDS of fuels. Feedstocks for diesel fuel, such as atmospheric gas oil and LCO from FCC, contain some nitrogen compounds ${ }^{(103)}$. SK in Koria has developed a new process, SK HDS Pretreatment Process that enables the refiners to produce economically ultra-low-sulfur-diesel of below $10 \mathrm{ppmw}^{(104,105)}$. It is known that nitrogen compounds can inhibit HDS on catalyst surface due to competitive adsorption. Adsorption removal of nitrogen compounds is used as a pretreatment before conventional HDS processing. Using a solid adsorbent, this process is based on the adsorptive removal of nitrogen containing compounds (NCCs) from the feedstock prior to conventional HDS units. In the SK HDS Pretreatment Process, the feedstock to the HDS unit is pretreated, and $90 \%$ or more of NCC in the feedstock is removed, resulting in higher desulfurizatin in a conventional HDS unit. It was found that the degree of improvement in HDS is proportional to the degree of NCC removal. SK HDS Pretreatment Process is claimed to be a cost-effective method for refineries to choose for 10 ppmw ULSD production. The SK HDS Pretreatment Technology has a simple process configuration (Fig. 7). The process consists of parallel vertical vessels with adsorbent beds, adsorption solvent circulation system, two stripping 
columns and associated pumps and overhead system. The diesel feedstock is passed over one of the adsorbent vessels followed by stripping to remove a small amount of desorption solvent. Nitrogen bearing NCCs are adsorbed it the adsorber. In the desorption cycle the adsorbed NCCs are removed from the off-line adsorbent bed and stripped in the second stripper column. The desorbed solvent is recycled in the process. Pretreated diesel blend is further processed in the downstream HDS unit. The rejected NCC stream, about 4 vol.\% for SK's LCO treatment cas, can be blended either into the refinery fuel oil pool or with Marine Diesel ${ }^{(106)}$.

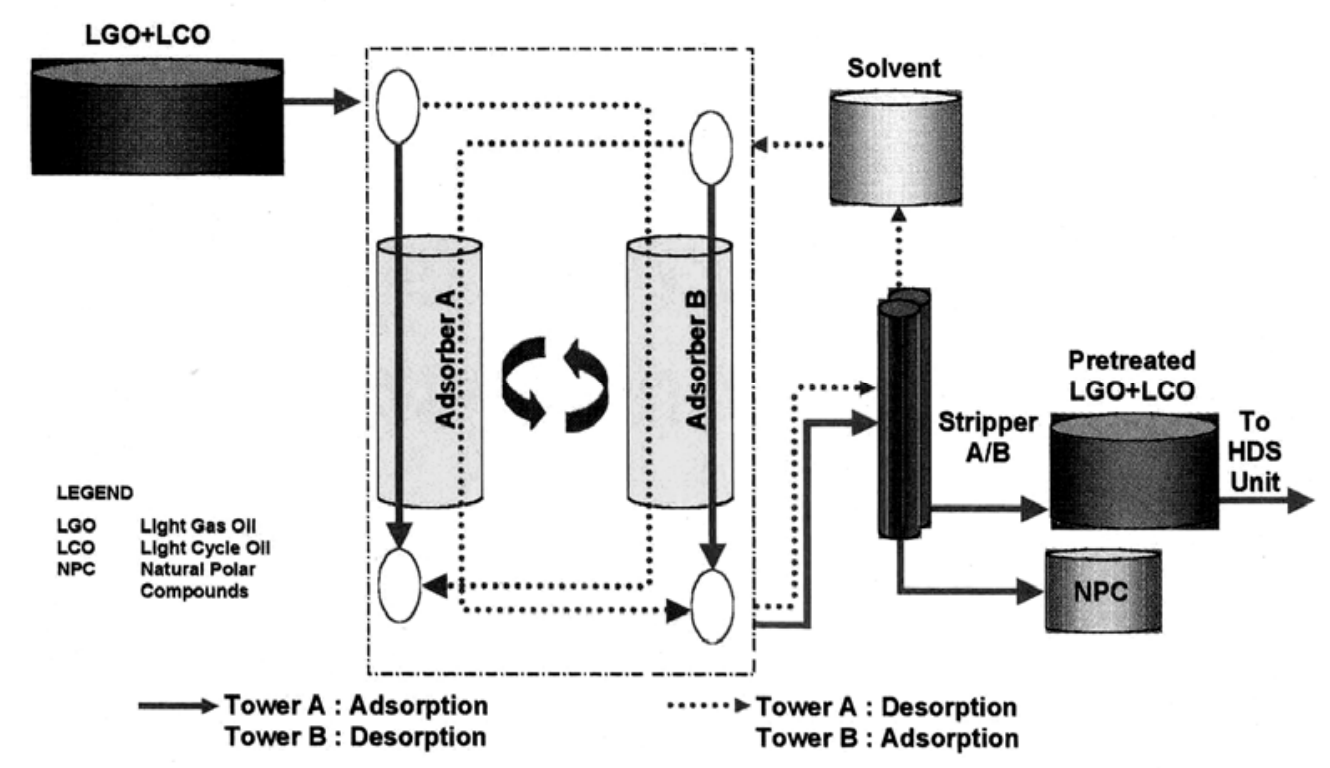

Fig. 7: SK HDS Pretreatment Process

\subsection{5- Charge complex formation:}

It is well established that among all sulfur-containing compounds present in gas oil, alkyldibenzothiophene compounds are the most refractory to the achievement of deep classical hydrodesulfurization. Focusing on these refractory sulfur compounds in gas oil, Milenkovic et al. ${ }^{(107,108)}$ explored an approach to selective elimination of alkyldibenzothiophenes from gas oil by formation of insoluble charge-transfer complexes. Milenkovic et al., have noted the electron-rich structure of alkyl DBTs and studied their ability to form charge-transfer complexes (CTC) with $\pi$-acceptors in order to develop a new highly selective method for their specific removal from gas oil. They reported the selective formation of insoluble CTC between dibenzothiophene derivatives and tetranitrofluorenone in synthetic solutions, which model the gas oil matrix. By the same procedure the global sulfur level was lowered in gas oils. A new method based on the selective formation of insoluble charge transfer complexes for removing the refractory compounds was described. Furthermore, they showed that the charge transfer complexation method is specific for dibenzothiophenes with regard to benzothiophenes. The complexation activity and selectivity have been correlated to the frontier molecular orbital energies and their shapes ${ }^{(108)}$. 


\subsection{6- Oxidation and extraction for desulfurizatin:}

Oxidation of sulfur atom in liquid phase, with or without radiation by ultrasound or UV light, followed by extraction of oxidized species can lead to desulfurization of diesel fuels ${ }^{(109,110)}$.

Shiraishi et al., ${ }^{(111,112)}$ explored a novel deep desulfurization process of light oil, effected by a combination of photochemical reaction and organic two-phase liquidliquid extraction. The process is comprised of two stages. The first consists of the transfer of the sulfur-containing compounds from the light oil to an aqueous-soluble polar solvent. This is then followed by the photooxidation and photodecomposition of the sulfur-containing compounds in the solvent by UV irradiation, using a highpressure mercury lamp. The operations are carried out under conditions of room temperature and atmospheric pressure.

With respect to the commercial oxidation process development, Petrostar announced a desulfurization technology, which removes sulfur from diesel fuels using chemical oxidation $^{(113)}$. Desulfurization of diesel fuel is accomplished by first forming a water emulsion with diesel fuel. In the emulsion, the sulfur atom is oxidized to a sulfone using catalyzed peroxyacetic acid. With an oxygen atom attached to the sulfur atom, the sulfur-containing hydrocarbon molecules become polar and hydrophilic and then move into the aqueuous phase. Like biodesulfurization, some of the sulfones can be converted to a surfactant which could be sold to the soap industry at an economically desirable price; the earnings made from the sales of the surfactant could offset some of the cost of oxidative desulfurization ${ }^{(113,114)}$.

\subsection{7- Biodesulfurization:}

An alternative approach is the use of microbial biocatalysts to perform the desulfurization reaction at low temperature and under atmospheric pressure. This process, known as biodesulfurization (was first described in 1950s), in which anaerobic bacteria able to convert DBT to biphenyl and hydrogen ${ }^{(115,116)}$. However, all these microorganisms presented very low desulfurizing activities not compatible with a practical process. Many aerobic bacteria are able to degrade DBT either by a ring destructive pathway without removal of the sulfur or by a completely destructive pathway in which DBT is mineralized ${ }^{(117)}$. Such metabolic pathways are not applicable to petroleum desulfurization since they lead to a loss of the fuel energetic value.

At the beginning of the 1990s, the research in biodesulfurization was intensified due to the implementation of more stringent regulations on the sulfur content in fuels, Biodesulfurization became relevant only since 1992 when several aerobic bacteria were isolated most of them belonging to the genus Rhodococcus, able to selectively extract the sulfur atom from DBT molecule without degrading its carbon Skeleton ${ }^{(118)}$. Therefore, the energetic value of the fuels is not affected since DBT is not degraded but only transformed into 2 hydroxybiphenyl (2HBP). This product is recycled to the organic phase constituted by the fuel itself, while the sulfur is eliminated in the form of inorganic sulfate in the aqueous phase containing the biocatalyst (Fig. 8). The first isolated and patented Rhodococcus strain, R. erythropolis IGTS8, is the basis of the biodesulfurization process proposed by ENCHIRA Biotechnology Corporation (ENBC), formerly Energy Biosystems Corporation $(E B C)^{(118)}$. The metabolic pathway 
for desulfurization has been elucidated and the enzymes and genes implicated have been isolated $^{(119,120)}$.

Other strains able to efficiently desulfurize substituted DBTs have been reported ${ }^{(121)}$. As in the case of HDS, substituted DBTs in positions 4 and 6 are the most difficult to biodesulfurize due to steric hindrance ${ }^{(122)}$. Surprisingly, a Sphingomonas strain was reported to desulfurize more efficiently the sterically hindered substituted DBTs than $\mathrm{DBT}^{(123-125)}$.

Biodesulfurization of middle distillates was reported using either wide-type or genetically engineered Rhodococcus strains, and the extent of sulfur removal was shown to be dependent on the reaction conditions and the initial sulfur content of the fuel. For instance, the sulfur content of a middle distillate not HDS treated was reduced from 20000 to 14000 ppmw using wild type Rhodococcus sp. strain ECRD$1^{(126)}$. When the same strain was used to desulfurize a middle distillate already treated by an aggressive HDS, the sulfur content was reduced from 669 to 56 ppmw $^{(127)}$. Hydrogenation and hydrogenolysis (occurring during HDS) might facilitate the oxidative pathways. The sulfur compounds left after HDS are less reactive toward hydrogen, but probably they are more reactive toward oxygen, creating an advantageous position for enzymatic catalysis compared to conventional HDS.

Three main factors have limited the implementation of the microbial desulfurization, including the technology proposed by Energy Biosystems Co.: (1) the large amounts of water necessary for the microbial metabolism; (2) the long residence time in the process that makes the reactor volumes unthinkable, and (3) the limited microbial metabolization on the large variety of chemical structures found in the organosulfur compounds existing in the petroleum. None of these problems have been solved yet.

This limitation might be addressed by using enzymes instead of whole microorganisms. Enzymes require less water than microorganisms to be active and stable in organic solvents and, theoretically, only a film of water covering their surface should be sufficient for catalysis to occur. The fuel itself could be the organic solvent, minimizing the addition of water.

An enzymatic process for fuel desulfurization has been described ${ }^{(128,129)}$. This method is based on the biocatalytic oxidation of organosulfides and thiophenes contained in the fuel with hemoproteins to form sulfoxides and suflones, followed by a distillation step in which these oxidized compounds are removed from the fuel.

This enzymatic process could be applied after a conventional hydrodesulfurization using a reactor with the immobilized enzyme. The challenge is still to have an enzymatic preparation able to perform the sulfur oxidation directly in the petroleum fraction without addition of water, and stable under the conditions found in the refinery. 


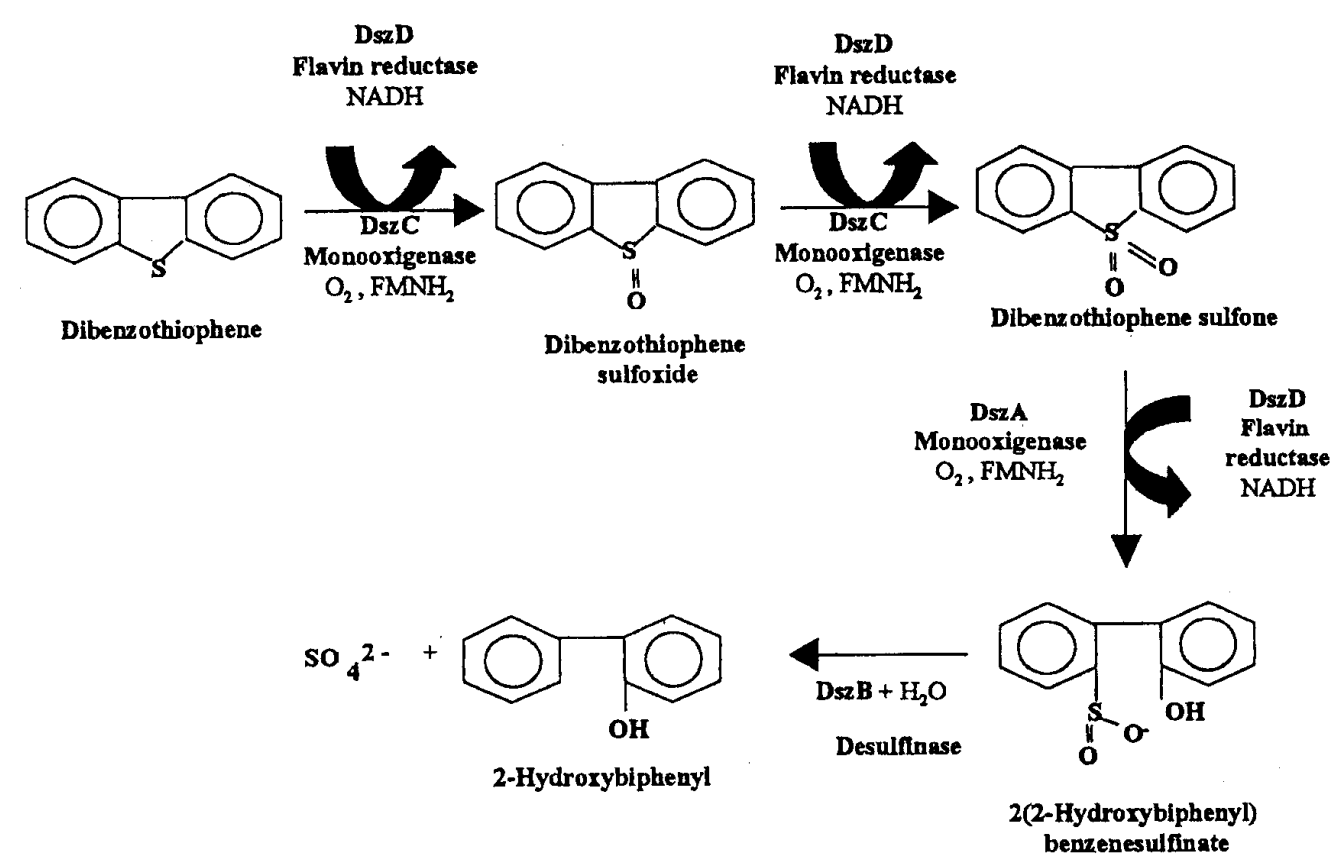

Fig. 8: Metabolic Pathway of DBT Desulfurization by Rhodococcus Erythropolis IGTS8

\section{5- PRE-FCC FEED HYDROTREATING AND LCO UNDERCUTTING:}

\section{1- Pre-FCC feed hydrotreating for sulfur reduction in LCO:}

The diesel fuel is produced form several blending stocks, of which light cycle oil (LCO) from FCC is a major blending stock that contributes to the sulfur in diesel pool. Sulfur could be removed from distillate material early or late in the refining process. Early in the process, the most practical place to remove sulfur is prior to the FCC unit. The FCC unit primarily produces gasoline, but it also produces a significant quantity of LCO. LCO is high in aromatics and sulfur, and contains a relatively high fraction of the sterically hindered DBT-type compounds. Many refineries already have an FCC feed hydrotreating unit; the LCO from these refineries could contain a much lower concentration of sterically hindered DBT compounds than refineries not hydrotreating their FCC feed ${ }^{(131-137)}$. Adding an FCC feed hydrotreating is much more costly than distillate hydrotreating. Just on the basis of sulfur removal, FCC feed hydrotreating is more costly than distillate hydrotreating, even considering the need to reduce gasoline sulfur concentrations, as well. This is partly due to the fact that FCC feed hydrotreating by itself is generally not capable of reducing the level of diesel fuel sulfur to those being considered in this rule. However, FCC feed hydrotreating provides other environmental and economic benefits.

FCC feed hydrotreating decreases the sulfur content of gasoline significantly, and reduces sulfur oxide emissions from the FCC unit. Economically, it increases the yield of relatively high value gasoline and LPG from the FCC unit and reduces the formation of coke on the FCC catalyst. For individual refiners, these additional benefits may offset enough of the cost of FCC hydrotreating. Fig. 9 depicts a simplified representation of the combined FCC-feed hydrotreating and FCCU. 


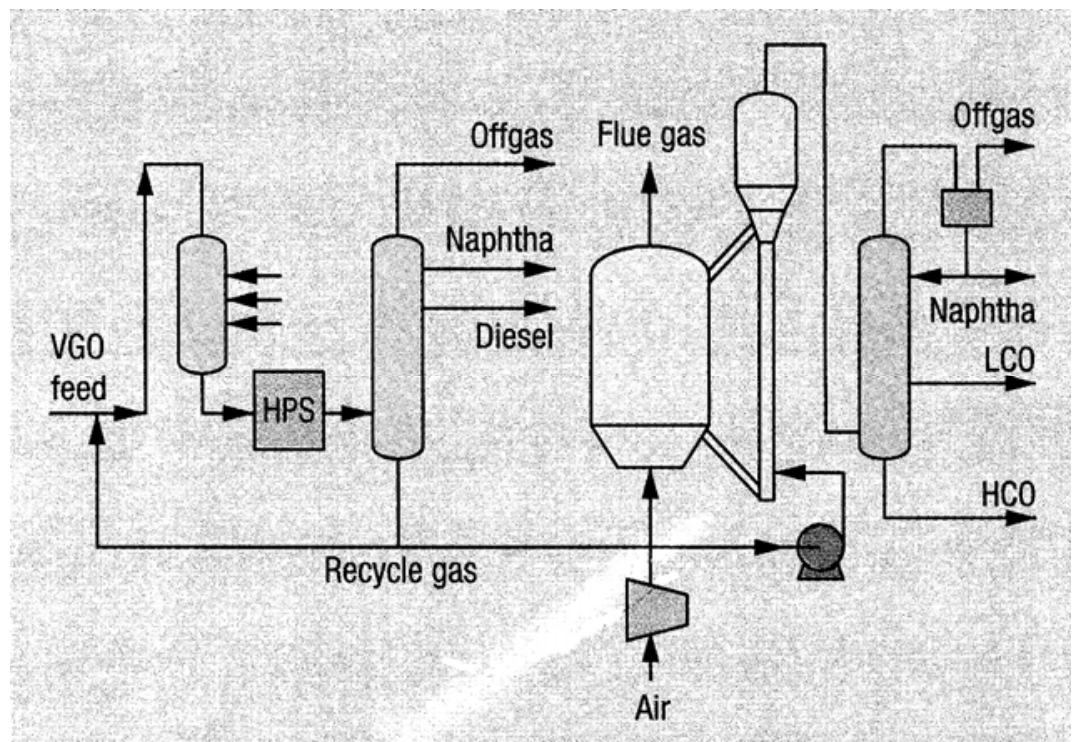

Fig. 9: Simplified Flow Diagram of FCC Hydrotreater and FCCU

\section{2- Undercutting LCO:}

It is conceivable that the sulfur-rich fraction, if they have a narrow boiling range, could be separated out in distillation operation. The primary stumbling block preventing the simple desulfurization of distillate to sulfur levels meeting the 15ppmw cap is the presence of sterically hindered compounds, particularly those with two methyl or ethyl groups blocking the sulfur atom. These compounds are found in greatest concentration in LCO, which itself is highly aromatic. These compounds can be desulfurized readily if saturated. However, due to the much higher hydrogen cost of doing so, it is better economically if this can be avoided. Because these compounds are inherently large in molecular weights due to their chemical structure, they distill near the high end of the diesel range of distillation temperatures. Thus, it is possible to segregate these compounds from the rest of the cracked stocks via distillation and avoid the need to desulfurize them. Once separated, this LCO material could be mixed into the refinery streams currently being used to produce off-highway diesel fuel and heating oil. While this heavy LCO material could be shifted to other markets, this does not necessarily have to be the case. Under certain conditions, this material can be cycled to the FCC unit ${ }^{(138,139)}$. For this to be feasible, the refiner must hydrotreat the FCC feed at a pressure sufficient to desulfurize the sterically hindered sulfur containing compounds and the feed hydrotreater must have sufficient excess capability to handle the additional material. This material could be also be sent to an existing hydrocracker, if sufficient capacity existed, and converted into gasoline blend-stock. It could also be hydrotreated separately under more severe conditions to remove the sulfur. This would entail higher hydrogen consumption per barrel of treated material because of some aromatic saturation. However, the amount of material being processed would be small ${ }^{(6)}$. 


\section{6- FUTURE TRENDS:}

\section{1 - Synthetic fuel technologies:}

\subsection{1- Fischer - Tropsch Gas - To - Liquids (GTL):}

Another source of low aromatic, high hydrogen content diesel is gas-to-liquids conversion, an area receiving much interest recently ${ }^{(140)}$. In this case, diesel is derived from natural gas rather than petroleum in catalytic processing equipment most likely located at a gas reserve rather than at a refinery.

An example of Fischer-Tropsch (F-T) diesel is that produced by the advanced gas conversion process, AGC-21, developed by Exxon for converting natural gas to liquid iso-paraffins virtually free of typical emission - causing impurities. The AGC-21 process, as shown in Fig. 10, comprises multiple new technologies within three main process blocks: synthesis gas generation, hydrocarbon synthesis and hydroisomerization. This process, which has been described previously ${ }^{(141)}$, first brings about the conversion of natural gas or methane to hydrogen and carbon monoxide. This is accomplished by contacting methane with steam and limited oxygen in a catalyzed fluid bed reactor where steam reforming and catalytic partial oxidation occur in a single vessel.

The hydrogen - carbon monoxide syngas is then converted almost exclusively to linear paraffins in a novel slurry reactor using a high productively, cobalt based hydrocarbon synthesis catalyst. These hydrocarbons are produced at high levels of syngas conversion. The full-range, primarily normal paraffin product contains significant $650^{\circ} \mathrm{F}+$ waxy material which is a solid at room temperature and melts above $250^{\circ} \mathrm{F}$ and which is unsuitable for pipeling or transporting in conventional crude carriers. The final step, accomplished with proprietary catalysts in a fixed or trickele bed reactors, mildly isomerizes any normal paraffines to slightly branched molecules which make excellent feeds for refineries and chemical plants. This step along with hydrocarbon synthesis can be altered to control the selectivity and yield of liquids from the process. An AGC-21 plant could be configured to produce a variety of products; on scheme of particular interest produces only light, clean products with diesel yield approaching $80 \%$ with the balance as naphtha ${ }^{(142)}$. The AGC-21 process is a good example for providing new options for meeting future clean fuels requirements.

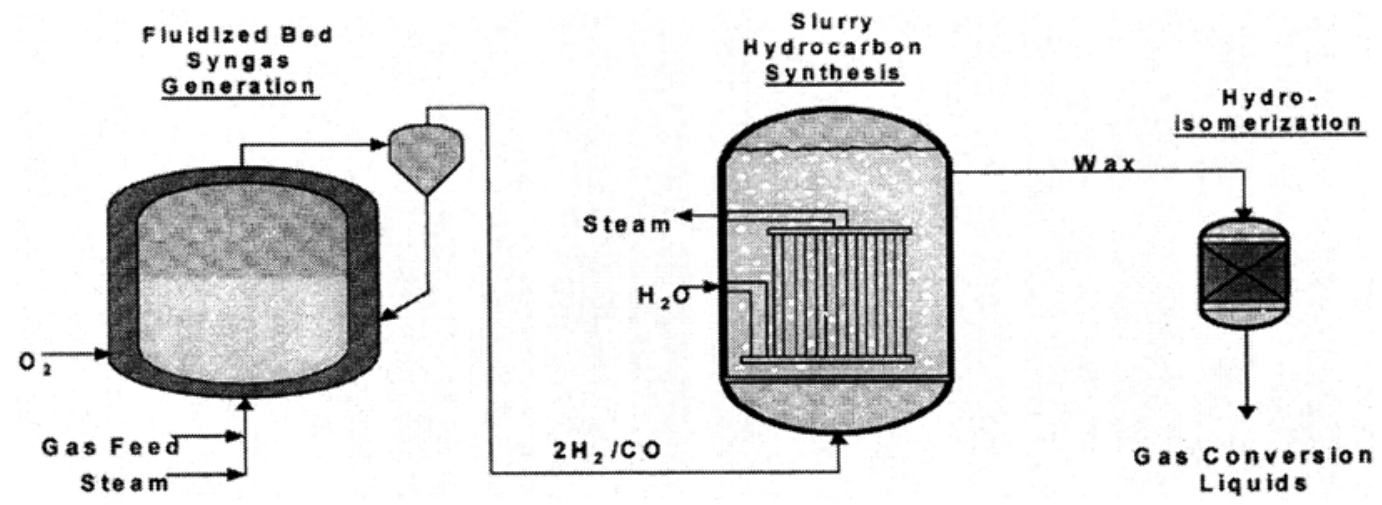

Fig. 10: Exxon's AGC-21 Process 


\subsubsection{Global biofuel developments:}

Biodiesel is a renewable and biodegradable fuel refined from vegetable oil (or animal fat). It is rapidly gaining momentum in the US as an alternative fuel source for diesel engines. Compared to petroleum diesel, biodiesel is environmentally friendly and is government mandated. It reduces carbon monoxide, carbon dioxide, sulfur dioxide,hydrocarbons and other particulate matter emissions that cause respiratory damage. Biodiesel also eliminates the cloud of dense, black smoke normally associate with diesel vehicles. It also has better lubricity than diesel fuel because of its higher viscosity. In addition, it represents a renewable source of energy.

Two processing routes for converting vegetable oil into diesel. The conventional processing root for diesel production is via transesterification where a vegetable oil or animal fat is reacted under heat with an alcohol, in the presence of a catalyst. The chemical reaction products are an alkyl ester, commonly referred to as a biodiesel and glycerol (Fig. 11). However, it must be emphasized that, even though the transesterification process is relatively straight forward, homemade biodiesel is not going to generate the highest-quality product, it will most probably contain impurities like residual alcohol, moisture and unreacted vegetable oil.

The hydroprocessing route uses hydrogen to remove oxygen from the triglyceride molecules ${ }^{(143,144)}$. This is the route used in the new process to produce green diesel. While hydroprocessing was clearly the chemistry preferred for refinery applications, how to implement it in a process design is not obvious. Two options can be considered:

- Co-processing in an existing distillate hydroprocessing unit.

- Building a standalone unit as shown in Fig. 12.

In the process shown in Fig. 13, vegetable oil is combined with hydrogen, brought to reaction temperature and then sent to the reactor where the vegetable oil is converted to the green diesel product. This product is separated from the recycle gas in the separator, and the liquid product is sent to a fractionation section.

Biodeisel and bioethanol based on seeds and fruits of plants alone are not capable of meeting growing energy demand. For this purpose, second generation biofuels are needed. These are made from feedstock based on the whole plant and biomass. Experts believe that biomass could satisfy one-third of the world energy demand ${ }^{(144)}$.

By 2050 , only about $50 \%$ of the energy will still originate from petroleum and natural gas, the balance will proceed from the coal and, increasingly, from biomass (Fig. 14). 


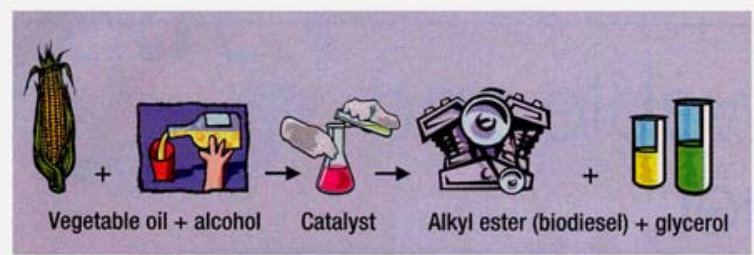

Fig. 11: Simplfiied transesterification of vegetable oil into biodiesel (alkyl ester)

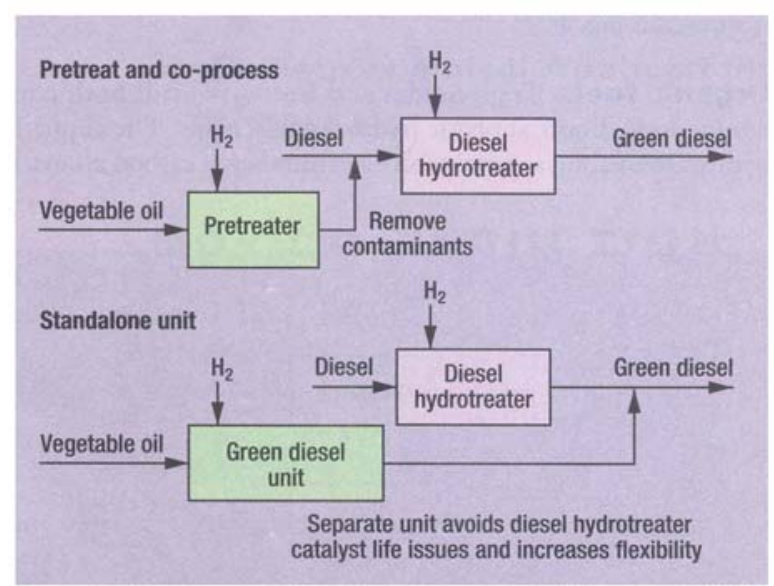

Fig. 12: Alternative vegetable-oil hydroprocessing routes to transportation fuels.

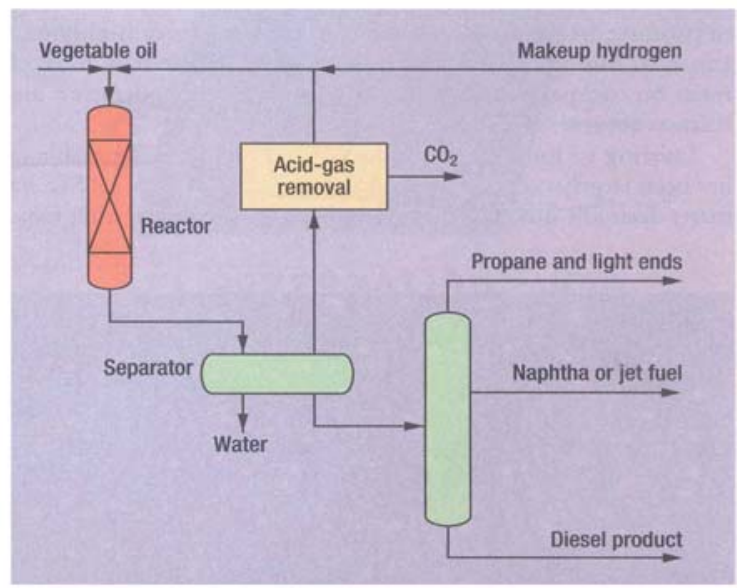

Fig. 13: The new green diesel process converts vegetable oil into fuels.

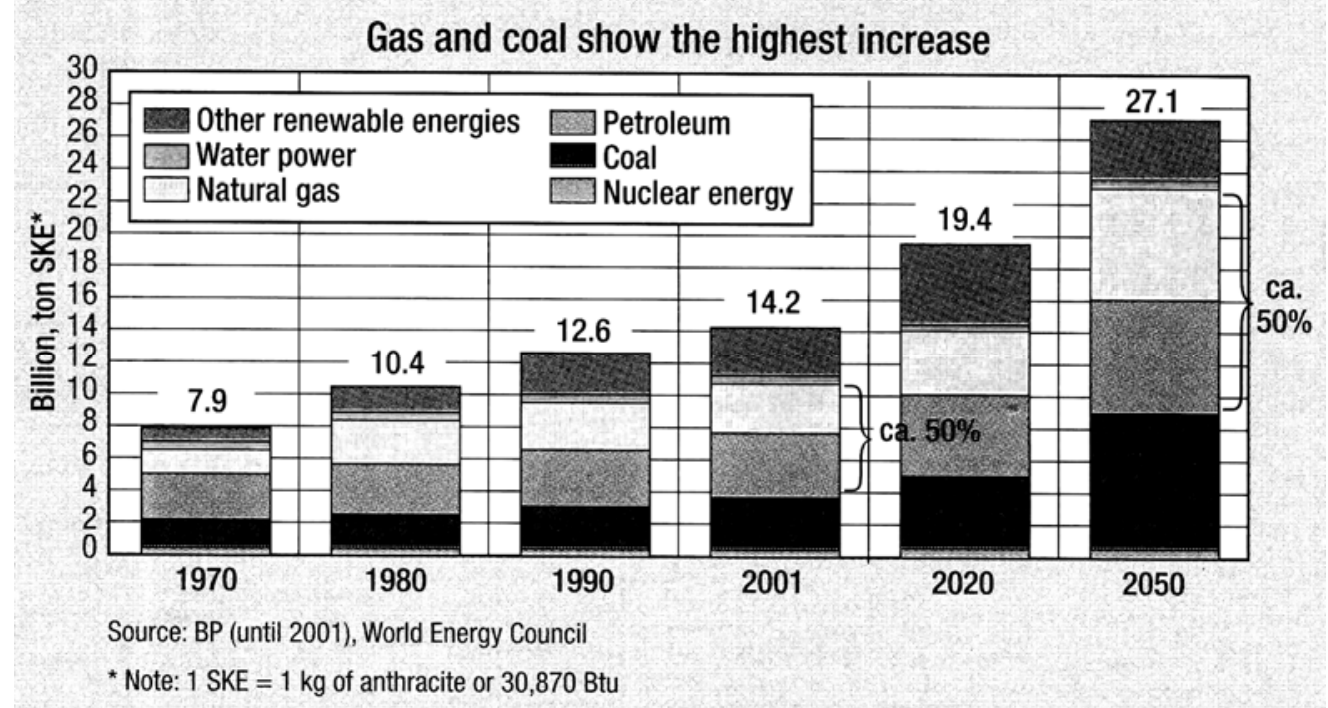

Fig. 14: Global energy consumption split by resources. In 2050 gas/oil is still forecast to supply approximately $50 \%$ of global demand.

\subsubsection{Research advances in biofuel technology for military jets:}

UOP L.L.C, a Honey well company, announced that it will accelerate research and development on renewable energy technology to convert vegetable and algae oils into military jet fuels. Advanced Research Projects Agency, is to develop and commercialize a process to produce jet propellant 8 (JP-8) used by US and NATO militaries. Fuel produced by the new process will have to meet stringent military 
specifications and is expected to achieve $90 \%$ energy efficiency for maximum conversion of feed-to-fuel, reduced waste and lower production costs. ${ }^{(145)}$

\subsection{Desulfurization unit for fuel cell technologies:}

Fuel cell technology is a new highly efficient alternative to fossil fuels for producing electrical power while having the additional benefit of not polluting the environment. Since fuel cells rely on chemistry and not combustion, emissions from this system type are much smaller than emissions from the cleanest combustion processes. Fuel cells work when electrochemical energy converts hydrogen $\left(\mathrm{H}_{2}\right)$ and oxygen into water, thus producing electricity. The proton exchange membrane (PEM) fuel cell has the broadest application potential with fuel cell technologies and subject to extensive research. However, $\mathrm{H}_{2}$ is difficult to store and distribute due to diffusion problems and explosion risks. Consequently, it is necessary to use a specialized high pressure storage tank.

This problem is addressed by utilizing a reformer which turns hydrocarbon or alcohol fuels into $\mathrm{H}_{2}$. The reformer extracts $\mathrm{H}_{2}$ from $\mathrm{H}_{2}$-rich fuels like methanol, natural gas, petroleum, gasoline and even biogas or biodiesel, and directly feeds the $\mathrm{H}_{2}$ gas to fuel cell.

The core of the PEM fuel cell is the platinum ruthenium anode-catalyst (Fig. 15). However, this is very sensitive to numerous impurities like sulfur and can be easily damaged. Fuel cell longevity is mostly dependent on feedstock impurities. Thus, if $\mathrm{H}_{2}$ is to be produced from $\mathrm{H}_{2}$-rich fuels using a reformer, the sulfur in the hydrocarbon fuels must be removed from the feedstock extending the fuel cells life.
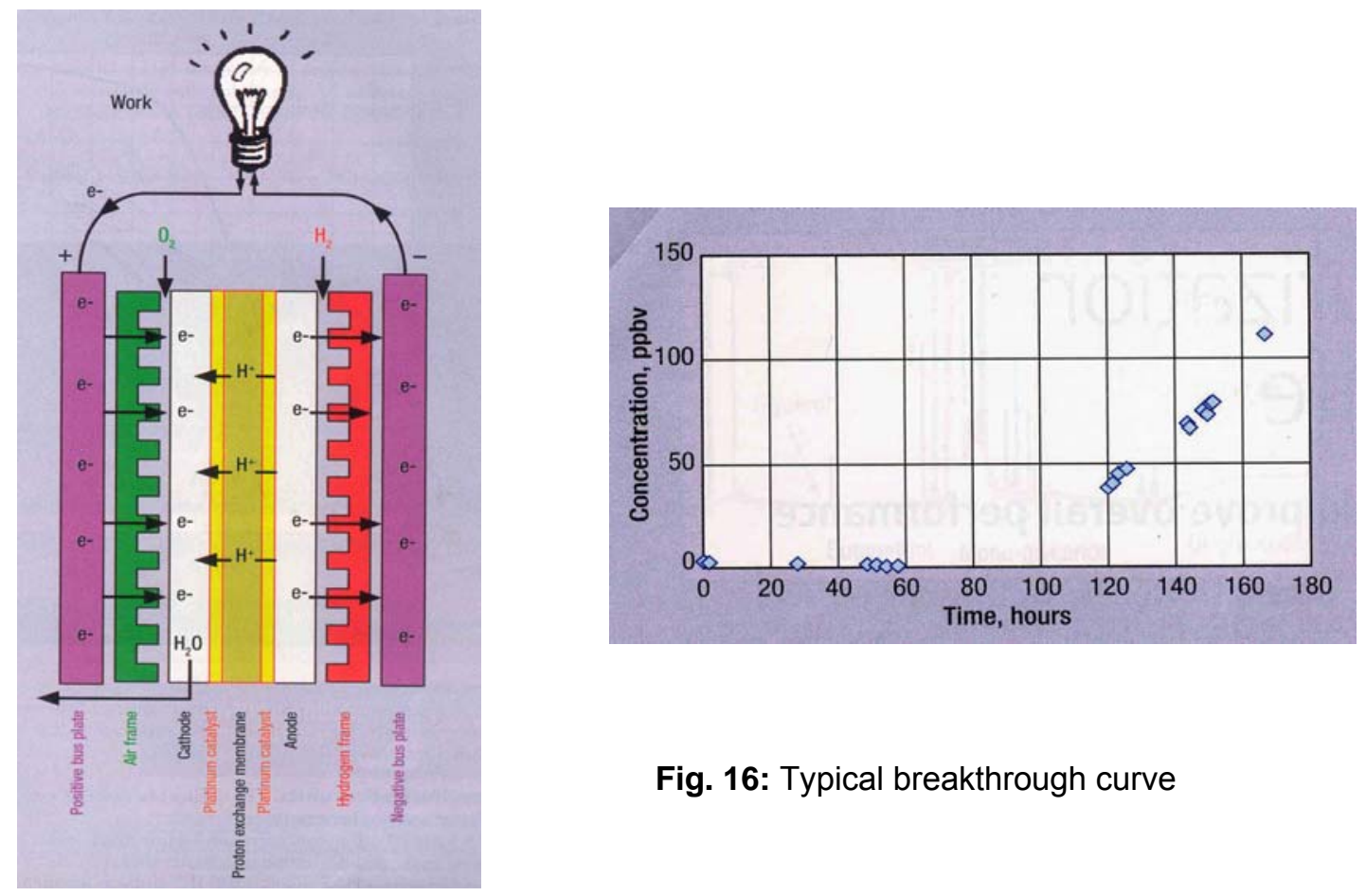

Fig. 16: Typical breakthrough curve

Fig. 15: Proton exchange membrane (PEM) fuel cell

Recent developments have demonstrated that it is possible to make feedstock for fuel cells practically sulfur-free by using a desulfurization unit. During this process 
stage, a total sulfur analyzer my be used to record sulfur concentrations in the desulfurization units outlet stream over time, producing "breakthrough curves (Fig. 16). As a result of these measurements, the quality (residual sulfur) and capacity (life cycle time) of the desulfurization unit are evaluated.

\section{7- CONCLUSION:}

Although the petroleum refining industry is very mature, ongoing changes in legislative requirements and engine design will continue to challenge the industrial to make changes in fuel composition. Significant advances in catalysis science and technology will be needed to meet the challenge. This provides room to obtain competitive advantage through the development of superior technology options and, as a result, there is intense industrial activity to meet the clean fuels challenge of providing cleaner fuels to the consumer from more difficult feedstocks at the lowest cost.

\section{REFERENCES:}

[1] Haelsig, C.P., and Turner, J., Hydrocarbon Process. 85(2) 41(2006).

[2] Sayles, S., and Bailer, J., Hydrocarbon Process. 84(9) 87 (2005).

[3] Sayles, S., and Ohmes, R., Hydrocarbon Process. 84(2) 39 (2005).

[4] Chou, T.-S., World Refining 14(1) 26 (2004).

[5] EPA, US Environmental Protection Agency, April 2001, http://www .epa.gov/fedrgstr/EPA-AIR/2001/April/Day-13/a 8927.htm.

[6] EPA - Diesel RIA, United States Environmental Protection Agency, Air and Radiation, EPA 420-R-00-026, December 2000.

[7] EPA, United States Environmental Protection Agency, February 2001.

[8] EPA, US Environmental Protection Agency, April 2003. http://www .epa.gov/nonroad/f03008.htm\#q3.

[9] Owen, K., Coley, T., Automotive Fuels Reference Book, $2^{\text {nd }}$ ed., Society of Automotive Engineers, Warrendal, PA, 1995, 963 pp.

[10] SAE, Society of Automotive Engineers, Warrendal, PA, February 1992.

[11] Palmer, R.E., and Johnson, J.W., Hydrocarbon Process. 83 (2) 39 (2004).

[12] Keith, H., World Refining 14 (2) 81 (2004).

[13] Swain, E.J., Oil Gas J. 8959 (1991).

[14] Swain, E.J., Oil Gas J. 9643 (1998).

[15] Swain, E.J., Oil Gas J. 10040 (2002).

[16] Choi, K.-H., Korai, Y., Mochida, I., Preprint Fuel Chem. Div. ACS. 48653 (2003).

[17] Romarow-Garcia, S., Hydrocarbon Process. 7917 (2000).

[18] Mathiak, I.J., Benz, W., Van Der Sar, I.K., and Van Doeselaar, I.M., Hydrocarbon Process. 85(2) 107 (2006).

[19] Song, K.C., Am. Chem. Soc. Div. Fuel Chem. Prepr. 47438 (2002).

[20] Raheel, S., and Graham, J.H., Catal. Today 59423 (2000).

[21] Batailc, I., Lemberton, J.L., Michand, P., Perot, G., Vrinat, M., Lemaire, M., Schulz, E., Breyssc, M., and Kasztclan, S., J. Catal. 191409 (2000).

[22] Topsoe, H., Knudsen, K.G., Byskov, L.S., Norskov, J.K., and Clausen, B.S., Stud. Surf. Sci. Catal. 12113 (1999).

[23] Mochida, I., Choi, K.H., J. Jpn. Petrol. Inst. 47 (3) 145 (2004). 
[24] Shin, S., Yang, H., Schakanishi, S., Mochida, I., Grudoski, D.A., Shinn, J.H., Appl. Catal. A 205101 (2001).

[25] Whitehurst, D.D., Isoda, T., Mochida, I., Adv. Catal. 42345 (1998).

[26] Song, C., Hsu, C.S., and Mochida, I., Chemistry of Diesel Fuels, Taylor \& Francis, New York, p.294, 2000.

[27] Gembicki, V.A., Cowan, T.M., and Brierley, G.R., Hydrocarbon Process. 86(2) 41(2007).

[28] Grisham, J.L., Chem. Eng. News, Jan. 721 (1999).

[29] Knudsen, K.G., Cooper, B.H. and Topsoe, H., Appl. Catal. A. 189(1) 205 (1999).

[30] Song, C., and Reddy, K.M., Appl. Catal. A. 1761 (1999).

[31] Song, C., and Reddy, K.M., in: Murugesan, V., Arabindoo, B., and Palanichamy, M. (Eds.) Recent Trends in Catalysis, Narosa publishing House, New Delhi, India, 1999 (Chapter 1) p. 1.

[32] Ma, X., Sakanishi, K., Isoda, T., and Mochida, I., in: occeli, M.L., and Chianelli, R (Eds.) Hydrodesufurization of Gas Oil Fraction and Model Compounds in Hydrotreating Technology for Pollution Control, Marcel Dekker, New York, p. 183, 1996.

[33] Schulz, H., Bohringer, W., Waller, P., and Ousmanova, F., Catal. Today 4987 (1999).

[34] Kabe, T., and Ishihara, A., Appl. Catal. A. 97 L1-L9 (1993).

[35] Kim, J.H., Ma, K, X., Song, C., Lee, Y.-K., and Oyama, T., Energy \& Fuels 19 353 (2005).

[36] Prins, R., Egorova, M., rothlisberger, A., Zhao, Y., Sivasankar, N., And Kukula, P., Catal. Today 11184 (2006).

[37] Farg, H., Sakanishi, K., and Mochida, I., Energy Fuels 13449 (1999).

[38] Egorova, M. and Prins, R., J. Catal. 225417 (2004).

[39] Choi, K.-H., Kunisada, N., Korai, Y., Mochida, I., and Nakano, K., Catal. Today 86277 (2003).

[40] Sumbogo, M.S.D., Yang, H., Choi, K.H., Korai, Y., And Mochida, I., Appl. Catal. A 252331 (2003).

[41] Salvator, T.S., Tom, R., And Justin, S., World Refining 12(10) 24 (2002).

[42] Chen, J., and Ring, Z., Fuel 83305 (2004).

[43] Rayo, P., Ramirez, J., Ancheyta, J., and Rana, M.S., Petrol. Sci. Tech. 25215 (2007).

[44] Hellgardt, K., Grutle, A., and Chadwick, D., Appl. Catal. A 22679 (2002).

[45] Marroquin, G., Ancheyta, J., and Diaz, J.A.I., Catal. Today 9875 (2004).

[46] Rayo, M.P., Ancheyta, J., Ramirez, J., and gutierrez-Alejandre, A., Catal. Today 98171 (2004).

[47] Jeremy, G., World Refining 14 (6) 22 (2004).

[48] Ramirez, L.F, Escobar, J., Galvan, E., Vaca, H., Murrieta, F.R., and Luna, M.R.S., Petrol. Sci. Tech., 22(1,2) 157 (2004).

[49] Topsoe, H., Clausen, B.S., and Massoth, F.E., Hydrotreating Catalysis: Science and Technology, Springer, Berlin, pp 310, 1996.

[50] Prins, R., Adv. Catal. 46399 (2001).

[51] Byskov, L.S., Hammer, B., Norskov, J.K., Clusen, B.S., and Topsoe, H., Catal. Lett. 47177 (1997).

[52] Helveg, S., Lauritsen, J.V., Lagsgaard, E., Stensgaard, I., Clausen, B.S., and Topsoe, H., J. Catal. 1971 (2001). 
[53] Daage, M., and Chiannlli, R.R., J. Catal. 194414 (1994).

[54] Song, C., and Ma, X., Appl. Catal. B 41207 (2003).

[55] Salvator, T.J., Richard, S., Tom, R., and Justin, S., World Refining 13 (1) 26 (2003).

[56] Perot, G., Catal. Today 86111 (2003).

[57] Breysse, M., Afanasiev, P., Geantet, C., and Vrinat, M., Catal. Today 865 (2003).

[58] Schacht, P., Hernandez, G., Cedeno, L., Mendoza, H., Ramirez, S., Garacia, L., and Ancheyta, J., Energy \& Fuels 1781 (2003).

[59] Ramirez, J., Macias, G., Cedeno, L., gutierrez-Alejandr, A., Cuevas, R., and Castillo, P., Catal. Today 98 (1-2) 19 (2004).

[60] Dzwigaj, S., Louis, C., Breysse, M., Cattenot, M., Belliere, V., Geantet, C., Virnat, M., Blanchard, P., Payen E., Inone, S., Kudo, H., and Yoshimura, Y., Appl. Catal. B 41181 (2003).

[61] Farog, H., Mochida, I., and Sakanishi, K., Appl. Catal. A 194147 (2000).

[62] Pawelec, B., Mariscal, R., Fierro, J.L.G., Greenwood, A., and Vasudevan, P.T., Appl. Catal. A 206295 (2001).

[63] Kaluza, L., and Zdrazil, M., Carbon 392023 (2001).

[64] Segawa, K., Takahashi, K., and Satoh, S., Catal. Today 63123 (2000).

[65] Pawelec, B., Navarro, R.M., Campos - Martin, J.M., Lopez Agudo, A., Vasudevan, P.T., and Fierro, J.L.G., Catal. Today 8673 (2003).

[66] Rana, M.S., Maity, S.K., Ancheyta, J., Murali Dhar, G., and Prasoda Rao, T.S.R., Appl. Catal. A 253165 (2003).

[67] Turaga, U., and Song, C., Am. Chem. Soc., Div. Petrol. Chem. Prepr. 4789 (2002).

[68] Song, C., Reddy, K.M., Leta, H., Yamada, M., and Koizumi, N., in: Song, C., Hsu, S., and Mochida, I. (Eds.), Chemistry of Diesel Fuels, Taylor \& Francis, New York, 2000, Chapter 7, p. 139.

[69] Wang, A.J., Wang, Y., Kabe, T., Chen, Y.Y., Ishihara, A., and Qian, W.H., J. Catal. 19919 (2001).

[70] Akzo Nobel, 2002. http://www.akzonobel-catalysts.com/html/hydroprocessing/ catalysts/hccatze.htm.

[71] Gerritsen, L.A., Presentation by Akzo Nobel at the WEFA Conference, Berlin, Germany, June 2000.

[72] Meijburg, G., Catalyst Courier No 46, Akzo Nobel, 2001.

[73] Plantenga, F.L., Catalyst Courier No. 47, Akzo Nobel, 2002. http://www.akzonobel-catalysts.com/html/catalystcourier/courier47/c47-a3htm.

[74] Iwamoto, R., Koshika, H., Takahashi, N., and Inamura, K., J. Jpn. Petrol. Inst. 48 (5) 319 (2005).

[75] Bej, S.K., Dalai, A.K., and Maity, S.K., Catal. Today 64333 (2001).

[76] Bharvani, R.R., and Henderson, R.S., Hydrocarbon Process. 81 (2002) 61.

[77] Lawler, D., and Robinson, S., Hydrocarbon Process, 80 61(2002).

[78] Sie, S.T., Fuel Process. Tech. 61149 (1999).

[79] Isoda, T., Ma, X., Nagao, S., and Mochida, I., J. Jpn. Petrol. Inst. 3825 (1995).

[80] Mochida, I., Sakanishi, K., Ma, X., Nagao, S., Isoda, T., Catal. Today 29185 (1996).

[81] Chaudhari, R.V., Jaganathan, R., Mathew, S.P., ALCHE 48 (1) 110 (2002). 
[82] Julcour, C., Jaganthan, R., Chaudhari, R.V., Wilhelm, A.M., and Delmas, H., Chem. Eng. Sci. 56557 (2001).

[83] Ancheyta, J., Marroqin, G., Angeles, M.J., Macias, M.J., Pitault, I., forissier, M., and Morales, R.D., Energy \& Fuels 161059 (2002).

[84] Castaneda - Lopez, L.C., Alonso - Matinez, F., Ancheyta - Juarez, J., Maity, S.K., Rivera - Segundo, E., and Matus - Guerra, M.N., Energy \& Fuels 15 1139 (2001).

[85] Tai-sheng, C., World Refining 14 (1) 26 (2004).

[86] Terrence, H., World Refining 13 (4) 4 (2003).

[87] Chou, T.-S., and Rost, K., D., World Refining 13 (4) 37 (2003).

[88] Maxwell, I.E., CATTECH 15 (1997).

[89] Dautzberg, F., CATTECH 354 (1999).

[90] Phillips Petroleum, http://www.fuelstechnolog.com/szorbdiesel.htm,December2001.

[91] Jason, G., Oil \& Gas J. Nov. 1972 (2001).

[92] Gislason, J., Oil Gas J. 9974 (2004).

[93] Velu, S., Watanabe, S., Ma, X., and Song, C., Prepr. Symp. - Am. Chem. Soc. Div. Fuel Chem. 48526 (2003).

[94] Velu, S., Ma, X., and Song, C., Prepr. Symp. - Am. Chem. Soc. Div. Fuel. Chem. 48693 (2003).

[95] Yang, R.T., Hernandez - Maldonando, A.J., and Yang, F.H., Science 30179 (2003).

[96] Ma, X., Lu, S., Yin, Z., and Song, C., Am. Chem. Soc. Div. Fuel. Chem. Prepr. 46 (2) 648 (2001).

[97] Ma, X., Sun, L., and Song, C., Catal. Today 77107 (2002).

[98] Ma, X., Sprague, M., Sun, L., and Song, C., Am. Chem. Soc. Div. Petrol. Chem. Prepr. 4748 (2002).

[99] Velu, S., Ma, X., and Song, C., Am. Chem.. Soc. Div. Fuel. Chem. Prepr. 47 447 (2002).

[100] Song, C., Catal. Today 86211 (2003).

[101] Bocich, I.V., and Moulijn, J.A., Fuel 82607 (2003).

[102] Turaga, U.T., and Song, C., Am. Chem. Soc. Div. Petrol. Chem. 46275 (2001).

[103] Laredo, G.C., Leyva, S., Alvarez, R., Mares, M.T., Castillo, J., and Cano, J.L., Fuel 811341 (2002).

[104] Min, W.A., J. Chem. Eng. 19601 (2002).

[105] Sano, Y., Choi, K., Korai, Y., and Mochida, I., Appl. Catal. B 49219 (2004).

[106] Ryu, J.-W., Yoo, I. - S., Kim, M.-J., Kim, G.-T., Lee, S.-W., and Min, W., World Refining 14 (7) 40 (2004).

[107] Milenkovic, A., Macaud, M., Schulz, E., Koltai, T., Loffreda, D., Vrinat, M., and Lemaire, M., Acad. Sci., Ser. II Fascicule C-Chim. 3 (6) 459 (2000).

[108] Milenkovic, A., Schulz, E., Meille, V., Loffreda, D., Forissier, M., Vrinat, M., Sautet, P., and Lemaire, M., Energy \& Fuels 13 (4) 881 (1999).

[109] Shiraishi, Y., Taki, Y., Hirai, T., and Komasawa, I.A., Ind. Eng. Chem. Res. 40 1213 (2001).

[110] Aida, T., Yamamoto, D., Iwata, M., and Sakata, K., Rev. Heteroatom Chem. 22241 (2000).

[111] Shiraishi, Y., Hirai, T., and Komasawa, I., Ind. Eng. Chem. Res. 37 (1) 203 (1998). 
[112] Shiraishi, Y., Hirai, T., and Komasawa, I., J. Chem. Eng. Jpn. 32 (1) 158 (1999).

[113] Chapados, D., in: Proceedings of the Paper Presented at the 2000 NPRA Annual Meeting, San Antonio, 2000.

[114] Li., C., Jiang, Z., Gao, J., Yang, Y., Wang, S., Tain, F., Sun, F., Sun, X., Ying, P., and Han, C., Chem. Eur. J. 102277 (2004).

[115] Kim, T.S., Kim, H.Y., and Kim, B.H., biotechnol. Lett. 12757 (1990).

[116] Armstrong, S.M., Sankey, B.M., and voordouw, C., Biotechnol. Lett. 171133 (1995).

[117] Oshiro, T., and Izumi, Y.B., biotechnol, Biochem. 631 (1999).

[118] Kilban, J.J., U.S. Patent (1992) 5, 104, 801.

[119] Rafael, V.-D., Eduardo, T., Brenda, V., and Sylvie, L.B., Energy \& Fuels 16 1239 (2002).

[120] Xi, L., Squires, C.H., Monticello, D.J., and Childs, J.D., Biochem. Biophys. Res. Commun. 23073 (1997).

[121] Lee, M.K., Senius, J.D., and Crossman, M.J., Appl. Environ. Microbiol. 61 4363 (1995).

[122] Oshiro, T., Hirata, T., and Izumi, Y., FEMS Microbial. Lett. 14265 (1996).

[123] Monticello, D., J. Curr. Opin. Biotechnol. 11540 (2000).

[124] Coco, W.M., Levinson, W.E., Crist, M.J., Hektor, H.J., Darzins, A., Pienkos, P.T., Squires, C.H., and Monticello, D., J. Nat. Biotechnol. 19314 (2001).

[125] Konishi, J., Ishii, Y., Onaka, T., Okumura, K., and Suzuki, M., Appl. Environ. Microbial 633164 (1997).

[126] Grossman, M.J., Lee, M.K., Prince, R.C., Garret, K.K., George, C.N., and Pickering, I., J. Appl. Environ. Microbiol. 65181 (1999).

[127] Grossman, M.J., Lee, M.K., Prince, R.C., Minak - Bernero, V., George, C.N., and Pickering, I., J. Appl. Environ. Microbial 671949 (2001).

[128] Ayala, M., Tinoco, R., Hernandez, V., Bremauntz, P., and Vazquez-Duhalt, R., Fuel Process. Technol. 57101 (1998).

[129] Lang, E.A., and Lin, Q., in: Song, C., Hsu., S., and Mochida, I (Eds.), Chemistry of diesel fuels, Taylor \& Francis, Philadelphia, (Chapter 9) 2000.

[130] Vazquez-Duhalt, R., Ayala, M., and Marquez Rocha, F., J. Photochemistry 58 929 (2001).

[131] Rashid, K., Hydrocarbon Process. 86 (2) 55 (2007).

[132] Couch, K.A., Seiber, K.D., and Van Opdorp., P.J., Hydrocarbon Process. 83(9) 77 (2004).

[133] Sarrazin, P., Bonnardot, J., Wambergue, S., and Morel, F., Hydrocarbon Process. 84 (2) 57 (2005).

[134] Dahlberg, A., and Mukherjee, U., Hydrocarbon Process. 86 (9) 111 (2007).

[135] Vander Laan, J., Sughrue, E.L., Dodwell, G., and Meier, P.F., Hydrocarbon Process. 85 (2) 49 (2006).

[136] Putek, S., and Gragnani, A., Hydrocarbon Process. 85 (5) 95 (2006).

[137] Rassadin, V.G., Durov, O.V., Vasil'ev, G.G., Gavrilov, N.G., Shlygin, O.Yu., and Likhlerova, N.M., Chemistry and Technology of fuels and Oils 43 (1) 1 (2007).

[138] Mayo, S.W., Akzo Nobel Catalysts, 1999.

[139] Gerristen, L.A., Sonnemans, H., Lee, S.L., and Kimbara, N., 2000 (http://www.aeat-env.com/sulfur-review/sr-AkzoNobel-html). 
[140] Kaufmann, T.G., Kaldor, A., Stuntz, G.F., Kerby, M.C., and Ansell, L.L., Catal. Today 6277 (2000).

[141] Edit Jr, C.M., Bauman, R.F., Eisenberg, B., Hochman, J.M., and Lahn, G.C., in: Proceeding of the $14^{\text {th }}$ world Petroleum Congres, June 1994.

[142] Ansell, L.L., Bauman, R.F., Eisenberg, B., and Everett, B.M., in: Proceedings of the World Petroleum conference on Refining Technology and Reformulated Fuels, March 1997.

[143] Stockle, M., Hydrocarbon Process. 86 (2) 77 (2007).

[144] Noweck, K., Hydrocarbon Process. 86 (2) 83 (2007).

[145] Select 5 at www. Hydrocarbon Processing.com/RS. 